\title{
LEXICAL PROXIMITY OF A XRI CORPUS TO KHOEKHOEGOWAB
}

\author{
Wilfrid H. G. Haacke \& Jan W. Snyman $\dagger$ \\ Milnerton, South Africa
}

\begin{abstract}
The present paper examines a corpus of some 1130 Xri concepts collected by Jan Snyman (UNISA) in the early 1970s. This collection is by far the largest corpus of vocabulary of self-declared "Griekwa" speakers available, and is unlikely to be surpassed in future, as the language is moribund. 1096 concepts of this Xri corpus are compared dialectometrically to the equivalents in Namibian Khoekhoegowab (Khoekhoe, formerly "Nama/Damara"). According to this method the rate of cognation between the Xri corpus and its Khoekhoe equivalents is $69 \%$ and consequently sets Xri aside as a lect distinct from Khoekhoegowab. While the entire word list is provided in an appendix, distinctive correspondences of the segmental phonology are discussed. The crucial question whether Xri had a three-tone system like !Ora or a four-tone system like Khoekhoegowab cannot be investigated reliably because of the absence of tonal data for Xri. The fact, however, that Xri (like !Ora) distinguishes certain voiced and voiceless consonants permits the conclusion that it too had a pre-tonogenetic system where voicing still is distinctive and - assumedly - has not caused tonal depression as in Khoekhoegowab. Although no dialectomeric comparison of !Ora and Xri lexicon has been undertaken, certain systematic phonological contrasts between these two lects set Xri aside also from !Ora as a distinct lect in this dialect continuum.
\end{abstract}

Keywords: Xri, Griekwa/Griqua,!Ora, Korana, Khoekhoegowab, tone, depressor consonants, accompaniment (of clicks), voice (of consonants)

\section{Introduction: Origin of the data}

The present paper examines a corpus of some 1130 concepts for which the late Prof. Jan Winston Snyman ${ }^{1}$ had collected Xri equivalents. He made over this corpus to me, W. H., around 1990. This collection on index cards is by far the largest corpus of vocabulary of self-declared "Griekwa" speakers available. The next largest corpus consists of illustrations subsumed under 112 German glosses by Meinhof (1930: 147-152). Some very short lists are too scant to offer meaningful insight into the lect. George Trevor Nurse (1975) reports the existence of an unpublished manuscript of his own, entitled A short annotated Xiri (Griqua) word list. I have had no access to it, though, and judging by the general research interests of Nurse, the words may rather be samples of Griekwa

\footnotetext{
${ }^{1}$ Jan Winston Snyman 8 July 1941 - 23 June 2002.
} 
Afrikaans. The explorer and zoologist Andrew Smith, who from 1834-36 was director of an expedition to explore Central Southern Africa, collected in his diary a list of 36 Xri words (including the numerals from 1-10) with !Ora equivalents (Kirby 1939/40). ${ }^{2}$

Hence, Snyman's collection warrants close consideration, even though virtually no metadata is available concerning the consultants. Three names of informants can be gleaned from certain cards with particular entries: Gert Maerman, Jan Kok from Campbell, and Katrina Brouers from Douglas, towns to the west of Kimberley in the Northern Cape. References to !Ora words do occasionally appear on cards (marked as $[\mathrm{K}]$ in this paper). Hence, it can be assumed with reasonable certainty that this collection of vocabulary is the one that J. A. Louw refers to:

"Use was also made of an unpublished vocabulary collected by J. W. Snyman,

F. Ponelis and J. A. Louw among the Korana and Griqua at Douglas and

Campbell on the Orange River" (Louw 1986: 150).

This Griekwa vocabulary can thus be assumed to have been collected by Snyman in the early 1970s: After he had in 1970 resigned from the Bureau for Indigenous Languages in Namibia to accept a post at the University of South Africa (UNISA) in Pretoria, and before 1975, when Fritz Ponelis in a workshop paper referred to fieldwork done by Jan Snyman and himself (Ponelis 1975: 60). While the three linguists from UNISA were engaged in joint fieldwork, it must have been Snyman who did the actual investigation of Xri and !Ora (and thus claimed ownership of the data), as Snyman was an established Khoesan phoneticist, while Prof Louw was a Bantuist (interested i.a. in Khoe loans in Bantu) and Prof Ponelis an authority in Afrikaans linguistics (i.a. the development of Afrikaans). As all three researchers have passed away, it appears to be no longer possible to glean any further information about this excursion. It is reasonable to assume that Profs Louw and Ponelis had an influence on the choice of concepts to be elicited, depending on their respective research interests. To give Jan Snyman due recognition for his fieldwork, I take the liberty to posthumously citing him as co-author, on the understanding that any subsequent editorial errors are solely my responsibility.

Snyman's cards were independently perused and annotated by Eliphas Eiseb, co-author of the Khoekhoegowab Dictionary (Haacke \& Eiseb 2002). The Xri data were never discussed by him and myself, though. For this reason the Khoekhoe equivalents provided in this paper are, when marked for tone, always extracted from the above dictionary. Khoekhoe equivalents not marked for tone were added to the cards by Eiseb, but do not appear in the dictionary. Most of the example sentences that he provided were included in this paper.

It must be taken into consideration that the data in all likelihood was not systematically verified subsequently by Snyman with Xri consultants, either for correctness of transcription or for correctness of rendering by the consultants, i.e. whether indeed the most appropriate Xri word was elicited for the gloss investigated. The latter problem was pragmatically handled in the dialectometric evaluation in this paper, especially when misunderstandings were apparent according to my judgement. With regard to the transcription one may rest assured that Jan Snyman was a most scrupulous phonetic fieldworker, having pioneered the phonological analysis of !Xuun/Jul'hoansi (Snyman 1970 and 1975). It is not known whether Snyman transcribed the words directly onto index cards, or whether he worked from audio-recordings. The cards render the impression, though, that they were compiled directly during the interviews. The non-availability of audio-recordings -

\footnotetext{
${ }^{2}$ I am indebted to Bonny Sands for drawing my attentionto this source.
} 
if they ever existed - now deprives us of the crucial opportunity to determine the tonological status of Xri with regard to the tonogenetic development from !Ora to Khoekhoe as expounded by Beach (1938: 247 et seq.). The best information we have on Xri tone is that Beach (1938: 237) found in 1936 that "Griet Booise, a Griqua informant from Beaufort West, employed exactly the same sort of intonation" as two competent speakers of !Ora had used a year earlier near Kimberley.

In view of the extreme paucity of data on Griqua lexicon, this database by Jan Snyman of well over a thousand lemmas does warrant publication irrespective of the uncertainty concerning the linguistic background of the consultants who identified themselves as "Griekwa".

\section{Ethnonym of the "Griekwa" or "Griqua"}

Before the data is discussed a reconsideration of the appropriate ethnonym for the so-called "Griekwa" is opportune. In recent publications (esp. Güldemann \& Fehn 2014: 4) the spelling Xiriis advocated. While it is fully justifiable to purge person-gender-number-markers (PGNs) like $-k w a$, $-q u a,-n a$ from Khoe ethnonyms - albeit the $-n$ of San,or better Saan, is inconsistently exempted three variants of this stem are advocated in the literature: Xiri or Xuri with a high vowel as V1, or $X r i$ with omission of V1. The variant Xiri should not be accepted without reservation, though. One reason is that the occurrence of the front vowel $i$ after the velar consonant $x$ violates the back vowel constraint, which stipulates that in Khoe languages a front vowel V1 $(i, e)$ cannot be preceded by a retracted consonant $C_{1}$ (like $x$ ). Furthermore, Beach (1938: 182) states that the "Griqua themselves" as well as all his Korana informants pronounced the root simply as $x r i$. He reports though, that while according to Meinhof the Griqua themselves (around 1928) used xri, the !Ora used xiri. Meinhof renders "Griqua" as xiri-kua-n-a in his !Ora glossary (1930: 93), but as xrikua- in his Griqua glossary (1930: 149). The fact that in !Ora -kua-is mistakenly treated as part of the stem suggests that these speakers had shifted from Khoe to Afrikaans to such an extent that the back vowel constraint no more applied as a phonological rule for them. An additional factor that may have contributed to the spelling with $i$ is that the Dutch letter $u$ is pronounced as [y], i.e. as a rounded high vowel. As Nienaber (1989:444) conjectures, giri is the unrounded pronunciation of Dutch spelling "guri". ${ }^{3}$ Note also the variant with the high front vowel, Xirikwana, Xurukwana for "Griekwa people" in the Appendix below, as recorded by Snyman. This variant complies with the back vowel constraint.

\footnotetext{
${ }^{3}$ An analogously misguided pronunciation due to spelling convention is the pronunciation of the word Khoekhoe as [khukhu] in Afrikaans. It is caused by the convention that the high back vowel [u] is spelt oe in Afrikaans.
} 


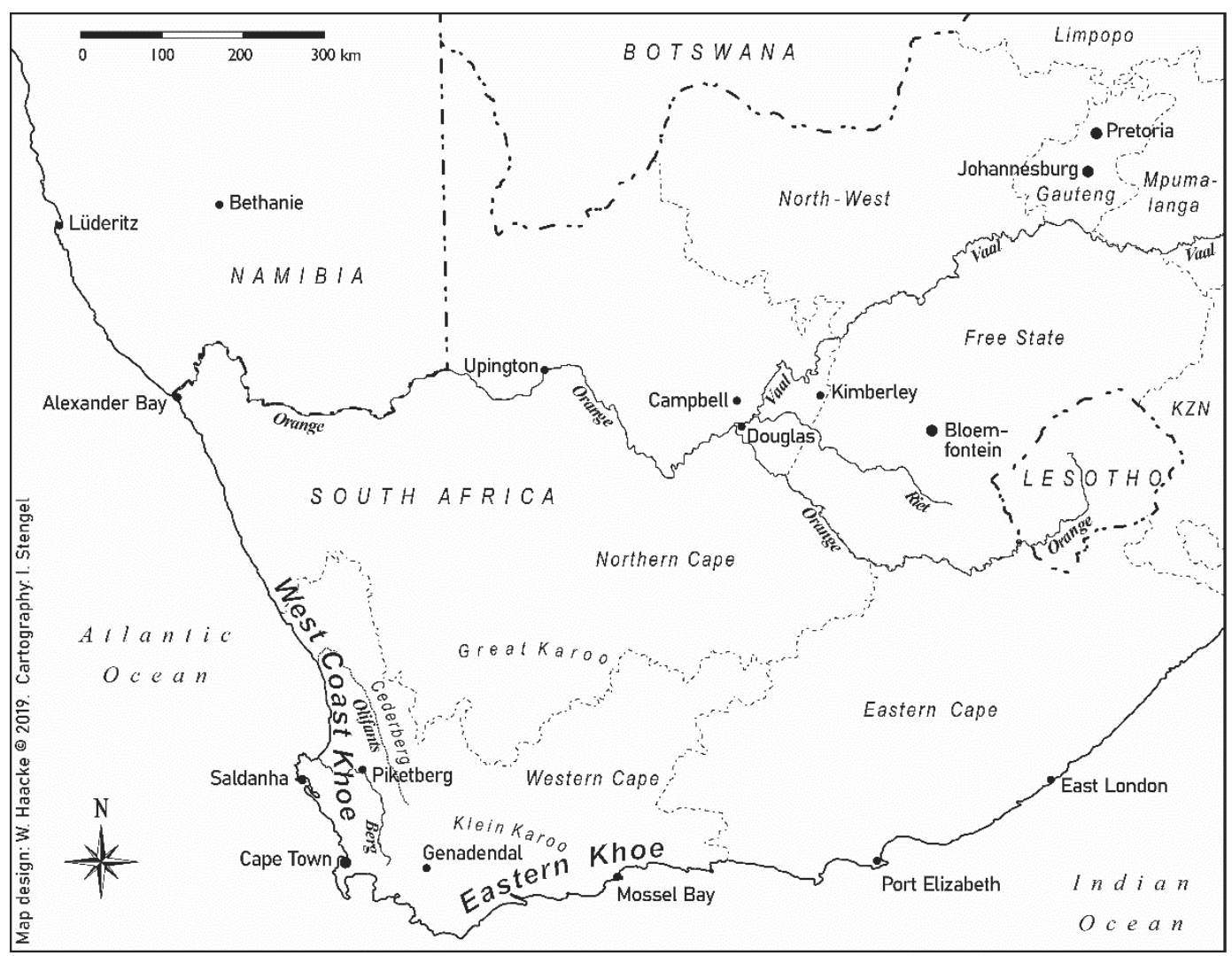

Figure 1 Orientation map of southern Africa

The first colonial records of a CV1CV2 stem all use the vowel $u$ instead of $i$ as V1. Nienaber (1989) in his meticulous and exhaustive survey of historical records points out that van Riebeeck in his Daghregister consistently (46 times) refers to the "Charigurina", i.e. $¥$ Kharixurina (Little Xuri), since they first appeared at the castle from south of the Bergriver at Saldanha ${ }^{4}$ in 1657. (Bear in mind that the Dutch letter $g$ normally had a fricative pronunciation [x].) Van Riebeeck describes their original whereabouts most exactly:

"... de Cleijne Chariguriquas, ..., die haer meest onthouden tusschen de Saldanhabaij ende ten halven tuschen 't Robben ende Dasseneijland, ongeveer 4 a 5 uijren gaens van de zeekant in 't land, ..."5

\footnotetext{
${ }^{4} 160 \mathrm{~km}$ from Cape Town.

${ }^{5}$ van Riebbeeck 1662 Memorie, in Nienaber 1989: 243.
} 
The $¥$ Kharixurina were, as the name implies, a smaller branch of the Griqua. The other branch was known as the "Grigriqua". Europeans usually contrasted them as the "Groot Charigurikwas", assuming that that the stem in Grigrikwa was a duplication of the root. Nienaber (1989:445) speculates that "geri-" or "geeri-" assimilated to "Grigri-".

Indeed, this stem mutatis mutandis is of the same type as the stem of Khoekhoe: The initial nominal root serves as attributive qualifier to the stemfinal head noun khoe. The free rendering of such - only apparently - reduplicated nouns is that it is a 'real/genuine/true/prototypical (Khoe or Xri)'; cf. also Haacke (2011). ${ }^{6}$ By implication the Xrixri thus are the 'Main Xri', in contradistinction to the 'Little Xri'.

Be it as it may, the meaning of neither variant, be it Xiri, Xuri, or Xri is known. It is contended here that, as the quality of V1 cannot be established beyond doubt for the etymon, the word in its most recent form as truly heard (viz. Beach 1983: 182), i.e. with elided V1 as Xri, should be accepted as the valid ethnonym as an instance of normal phonotactic reduction. While the elision of V1 does not occur frequently, it is manifested in other Xri words; e.g.Brip/Brikwa (Goat people, i.e. Tswana); cf. Khoekhoe Pirin from Tswana podi (goat).

The original Xri people thus essentially belonged to the West Coast Khoe, like the Nama. According to the historical sources as analysed by Nienaber (1989) the Little Xri were related to the 'Cochokwa' ('Saldanhars' or 'Smal Wangen', i.e.łÒóxóòn), who lived at Saldanha. According to van Riebeeck the latter were "den allergrootsten van al de Hottentoos" (Nienaber 1989: 265). The Little Xri were subservient to them and served them as herders. By about 1660, however, the $\ddagger$ Kharixurin revolted against their servitude under the fÖ́xóòn and disappeared into a territory north of the Olifants River (Nienaber 1989: 16).

The main Xri group, the Xrixri lived further inland on the northern/right side of the Berg River towards the present Piketberg and into the Cederberg. As they disseminated, they became ever more strongly hybridised. According to the physician and zoologist Martin Hinrich Lichtenstein the name "Griekwa" had disappeared by 1800 (Nienaber 1989:449). Lichtenstein, later Rector of the University of Berlin, in his report on an expedition from 1804-5 referred to them exclusively as "Bastardhottentotten". He only once mentions the term "Giriqua", and that as an example of an ethnonym long disappeared ("längst verschollen") in the Colony. These descendants of the former Xri interbred extensively with the descendants of the !Ora, who - while still in the Cape were associated with the Eastern Khoe clans - themselves were strongly hybridised and known as Bastards, after having migrated north. It was only through the influence of the missionary John Campbell that these mainly Dutch-speaking and largely impoverished descendants of the former Xri by 1816 had adopted the forgotten name "Griekwa" as autonym in place of "Bastard", which sounded demeaning to Europeans. Concerning the hybridization of the !Ora it is indicative that today Nama and Damara in Namibia, while being ignorant of the original Khoe history of the !Ora, will understand the term !Órà without hesitation as a reference to the socalled Rehoboth Bastards. Indeed, this community that had its origin in the Northern Cape ("Bushmanland") in the nineteenth century, has retained the term Bastard as part of its autonym.

After their exploratory tour in 1836 the missionaries Thomas Arbousset and Francois Daumas of the Paris Evangelical Missionary Society wrote that

\footnotetext{
${ }^{6}$ Ghomeshiet al. (2004) discuss a semanticaly similar kind of construction, known from phrasesin colloquial English like "It's tuna salad, not SALAD-salad", as "contrastive focus reduplication". The Khoekhoe construction does, however, not have reduplicative tonology (as in causatives) but attributive tonology: The first root has the citation melody and the second root (head) the sandhi melody: Khöèkhöe.
} 
"The Griquas are a mixed race, having the same characteristics, and almost the same manners, as the Bastaards speaking the same language, and intermarrying with them... For what african [sic] blood they have, the Bastaards are indebted entirely to the aborigines of the Cape colony. The Griquas trace theirs, in some measure, to the same source" (in Nienaber 1989:433).

An anonymous missionary "who resided a long time in the midst of them" is quoted in a letter from 1846:

'the Griquas ... are a people of very recent origin, their history scarcely extending further back than forty years... A slave, called Adam Kok ... purchased his freedom. ... He sold his little domain, and emigrated into the country of the Namaquas, where his subjects were increased by the addition of a considerable number of the natives. Mr Anderson ... led Adam Kok ... still further to the north, and with the assistance of Mr Campbell, he gave to the people a new code of written laws. The people were declared independent: they took the name of Griquas, and they agreed to acknowledge Kok and his descendants as their legitimate sovereigns..." (Nienaber 1989:433).

Adam Kok I, born in 1710 as son of a Dutch settler who had married a slave, married a daughter of the $\neq$ Khariaxurin ("Little Griqua") chieftainand in 1750 moved north over the Berg River to Piketberg with his family. With reference to this maternal ancestor his so-called "Baster" descendants of the northern Cape area replaced their ethnonym with Griqua in 1816.

The obvious question now arises, to what extent remnants of a genuine "Griekwa" lect had survived into the $20^{\text {th }}$ century. It must be considered that the descendants of the Xri had lived in close proximity not only to the !Ora but also the Orlam Nama (especially the !Amân who had also left the Colony for "Little Namaqualand" in the area between the Berg and Olifants Rivers), who later moved on to what was known as "Great Namaqualand" to the north of the Orange River where they became known as "Bethaniers". Beach, who did his research in the 1930s, grouped !Ora and Xri together "mainly because the boundary line between the two is very difficult to define. The Korana and the Griqua have intermingled on such a large scale that it is now almost impossible to find a pure representative of either tribe." (Beach 1938: 181).

\section{The Data ${ }^{7}$}

At first perusal of the cards the high number of Xri lexical items identical to those of Khoekhoe is striking and raises suspicion that there may be direct borrowings from Nama. Indeed, of the 1096 concepts considered for the comparison 846 or some $77 \%$ of the pairs consist of partial or full cognates, or - stated differently - only $23 \%$ of the Xri lexicon is independent of (Namibian) Khoekhoe. To reflect the extent of divergence of partial cognates the principle of weighting as used in dialectometrics ${ }^{8}$ is applied:

- For full identity of cognates, including cognates with regular sound correspondences, 4 points are allocated;

\footnotetext{
${ }^{7}$ I am endebted to Edward Elderkin for his comments and careful scrutiny of an earlier draft version of this paper.

8 cf. Möhlig 1983.
} 
- for morphological divergence (e.g. differing orders/combinations of morphemes in a compound stem, or morpheme omissions), 3 points; person-gender-number markers (PGNs) are not considered for comparison, as their usage can be arbitrary, and compounds with different head-nouns are not taken as cognates;

- for irregular phonological divergence, 2 points; As the Xri consultants occasionally appear to be uncertain about the correct click, probable full cognates are then rated as 2 instead of 4 in case of divergence;

- $\quad$ for multiple divergence or combined morphological and phonological divergence, 1 point.

In the case of alternative reflexes only one rating per gloss is provided, as determined by the closest pair of cognates available. When only a !Ora reflex is available, no rating is applied. Mismatches between Xri (non-)depressor consonants and Khoekhoe tone melodies are rated with 2 as phonological mismatch, eg.

back **ââåán.

As as the glottal stop release of $\|^{\prime}$ did not become a depressor in Khoekhoe (see below), the Khoekhoe melody should not commence with an extra-low tone.

According to this weighted calculation the rate of cognation between the Xri corpus and its Khoekhoe equivalents is $69 \%$ (to the nearest per cent).

3.1 Equivalents of Khoekhoe depressor consonants in Xri The essential question is to what extent the self-asserted Xri lexis represents authentic Xri lexis, i.e. lexis that is not a mere adoption of either Nama/Khoekhoe or !Ora vocabulary. This paper will be confined to comparing Xri and Khoekhoe. While the same question pertains to the status of Xri as against !Ora, it is not investigated here for reasons of space and as there are considerable lacunae in the available !Ora data bases ${ }^{9}$.

A brief introduction to the tonological system of !Ora and Khoekhoe should facilitate comprehension of the following arguments involving tone. As Beach (1938) has presented a reliable analysis of the tonology of the citation (i.e. basic) forms of !Ora roots, while no such systematic analysis has ever been presented for a Xri lexicon, the tonology of !Ora must be taken as the best representative of South African Khoe lects to compare to contemporary Namibian Khoekhoe. As will be argued below, it can be assumed that Xri had a tone system similar to that of !Ora. As Beach employs a tonological framework different to that of Haacke (1999), his findings will be summarized here in a way compatible with the approach of Haacke.

While Beach (1938: 236 et seq.) recognizes the (mono- or disyllabic) "root "10 as tone bearing unit, to which he assigns a rising or falling tone or "toneme", Haacke (1999) argues that a tonal contour or "melody" consisting of two register tonemes is assigned to the bimoraic root. In the latter analysis toneme and syllable are isomorphic. Beach's contoured "toneme" thus amounts to Haacke's "melody", which is made up of two register tonemes. Beach marks each "toneme" (i.e. melody) with a single distinctive symbol before the root.

\footnotetext{
${ }^{9}$ Cf. below for a reference to Haacke (2016), which is a separate investigation of the lexical proximity of $17^{\text {th }}$ Century Cape Khoekhoe and !Ora to contemporary Khoekhoe.

An Index of some 3100 !Ora roots was published in du Plessis (2018) after the compilation of this paper. du Plessis has consolidated all available printed sources and augmented them with recent field work.

${ }^{10}$ Beach (1938: 27) distinguishes "weak" roots and "strong" roots. His "weak" roots are ignored here as they are grammatical formatives.
} 
Because of a tonogenetic process, Khoekhoe has - through the development of an additional toneme lower than the three others - a total of four register tonemes, which can combine into six (major) bimoraic melodies. The !Ora system of Beach is hence re-interpreted here as consisting of three tonemes (combining into four melodies).

The four register tonemes of Khoekhoe are identified in the text in one of the following ways, depending on the context:

$\begin{array}{ll}\text { Khoekhoe } & \\ \text { "Extra-high": } & / 4 / \text { or / " / } \\ \text { "High": } & / 3 / \text { or } / \text { / } \\ \text { "Low": } & / 2 / \text { or } / \text { / } \\ \text { "Extra-low": } & / 1 / \text { or } / \text { "/. }\end{array}$

The most striking difference between !Ora and Khoekhoe phonology (as shown by Beach 1938: 247 et seq.) is the phenomenon that !Ora has certain egressive and ingressive consonants that, as rootinitial consonants, act as depressors in Khoekhoe and create the additional, "extra-low" tone. They are:

\section{The !Ora voiced plosives $\quad(b) d,$,$g ;$}

the egressive consonants realised as Khoekhoe fricative $h$ and nasal $m$, and aspirates $k h$ and $t s$

and

the click $(\mathrm{X})$ releases realised as $\mathrm{X} \boldsymbol{h}$ and $\mathrm{X} \boldsymbol{n}$ in Khoekhoe.

In the process of tonogenesis Khoekhoe looses the voice distinction between the three plosives $b, d, g$, and $p, t$ and $k$ respectively, as the distinction becomes transphonologised into tonological distinctions. The !Ora melodies "mid level" and "low-mid falling" transpose to the melodies /12/ and /13/ respectively in Khoekhoe, when depressed. Through tonogenetic splitting the four !Ora melodies (Beach: "tonemes") hence have six equivalent melodies in Khoekhoe:

\begin{tabular}{|c|c|c|c|c|c|}
\hline $\begin{array}{l}\text { !Ora melodies } \\
\text { (Beach: "tonemes") }\end{array}$ & $\begin{array}{l}\text { Khoekhoe } \\
\text { (Haacke) }\end{array}$ & elodies & Gloss & !Ora & Khoekhoe \\
\hline high level & $=\quad / 43 /$ & / ' / & one & $\operatorname{Tgui}^{11}$ & |güí \\
\hline high rising & /24/ & I'" I & cold & !khai & !khàï \\
\hline $\begin{array}{l}\text { non-depressor + mid-level } \\
\text { depressor + mid-level }\end{array}$ & $\begin{array}{l}/ 32 / \\
/ 12 /\end{array}$ & / & $\begin{array}{l}\text { snore } \\
\text { sing }\end{array}$ & $\begin{array}{l}-! \text { kharu } \\
-\| \text { nae }\end{array}$ & $\begin{array}{l}\text { !khárù } \\
>\text { >näè }\end{array}$ \\
\hline $\begin{array}{l}\text { non-depressor }+ \text { low-mid falling } \\
\text { depressor }+ \text { low-mid falling }\end{array}$ & $\begin{array}{l}/ 22 / \\
/ 13 /\end{array}$ & $\begin{array}{lll}1 & 1 \\
1 & 1 & 1\end{array}$ & $\begin{array}{l}\text { ostrich } \\
\text { rise }\end{array}$ & $\begin{array}{l}\text { 、lamis } \\
\text { ‘khâi }\end{array}$ & $\begin{array}{l}\text { làmìs } \\
>\text { khäí }\end{array}$ \\
\hline
\end{tabular}

\footnotetext{
${ }^{11}$ The !Ora instances are here spelt according to the Khoekhoe orthography.
} 
This means that while !Ora - and presumably Xri - had a three-tone system with tones equivalent to Khoekhoe /2/, /3/, /4/, Khoekhoe developed an additional, lowest tone /1/, giving it a four-tone system with tones $/ 1 /, / 2 /, / 3 /$ and $/ 4 / .^{12}$

It remains to be seen whether in Xri too the above depressor consonants correlate with the depressed melodies in Khoekhoe. If so, it can be assumed that Xri had a three-tone system similar to that of !Ora. The actual pronunciation of those melodies can no longer be retrieved, however.

A brief note on the orthographic conventions is opportune. For Khoekhoe the standardised spelling is used in this paper, but with the regular adaptation that so-called "long" vowels normally spelt with a macron are here spelt with double vowels in order to accommodate the two tone diacritics of the bimoraic root; e.g. !gāb (poison) is spelt !gáàb. In Snyman's Xri roots vowels have been doubled according to the canonic disyllabic $\mathrm{CV}(\mathrm{C}) \mathrm{V}$ structure of Khoe roots, so as to facilitate the comparison to the Khoekhoe roots. Snyman has not considered this principle, as there was no general awareness of it before about 1999.

Since tone is not indicated in Xri words, nasalised vowels in Xri are spelt with only a single vowel with circumflex like in the standardised Khoekhoe orthography, while in Khoekhoe two vowels appear with a subscript tilde under the first vowel, in order to accommodate the two tone marks; e.g.

Xrilnî Khoekhoe Inịı" (another).

Note that both vowels are nasalised.

- Third person masculine singular PGNs that are assimilated to a preceding nasal consonant are rendered as /(homorganic) nasal+i / in both lects, e.g. kx'ami>kx'ammi (lip).

- $\quad$ The nasal accompaniment of clicks (X) has been changed from Snyman's $n \mathrm{X}$ to $\mathrm{X} n$ for Xri, in line with Khoekhoe.

- The rendering of Xri clicks with voiced velar accompaniment has been kept as $\mathbf{g X}$ in Snyman's rendering, in order to highlight the contrast to the voiceless velar accompaniment, $\mathrm{X}$. Note that Snyman writes the voiceless velar accompaniment that usually is spelt as $\mathrm{X} k$ in !Ora, merely with a click X. Khoekhoe only has voiceless unaspirated accompaniments $\mathrm{X}$, as the voicing distinction has disappeared during tonogenesis.

It should be kept in mind that in the standardised orthography of Khoekhoe (as used here) the respective use of the letters for voiceless and voiced plosives reflects neither voicing nor the tonogenetic origin of words, but simply is an orthographic convention to distinguish three higher melodies from three lower melodies when tonal diacritics are not used, viz.

$$
\begin{aligned}
& p, t, k \text { for /' '/, / "/ and / "'/ } \\
& b, d, g \text { for / " '/, / "'/as well as / ' } /{ }^{13}
\end{aligned}
$$

\footnotetext{
${ }^{12}$ For a detailed discussion of tonogenesis in Khoekhoe, see Haacke 1999: 54 et seq.. For some minor sets of correspondences involving Khoekhoe /43/ and /24/, see Haacke 2008. These do not pertain to the present investigation, however.

13 This convention was introduced for Khoekhoe on the recommendation of Snyman while employed as educational planner in the Bureau for Indigenous Languages (p.c.) in order to distinguish homophones in the practical orthography where tone diacritics are not used; e.g. puru [pùrü] (knock over) vs. buru [pürú] (be amazed).
} 
In initial position these three plosives represent unaspirated plosives that are essentially voiceless. The intervocalic labial consonant (C2) in Khoekhoe has three free variants: a denti-labial fricative $[v]$, a bilabial fricative $[\beta]$ or a bilabial plosive $[\mathrm{b}]$. In line with general lenition and possible elision of $\mathrm{C} 2$, [v] occurs most frequently. In the spelling either $\mathrm{V} p \mathrm{~V}$ or $\mathrm{V} b \mathrm{~V}$ may be used to indicate the tonal melody, or a non-committal $\mathrm{V} w \mathrm{~V}$ may be used. Neither of these three letters implies a particular pronunciation of the labial. For the sake of simplicity this paper uses in Khoekhoe only $w$. Snyman without exception uses $b$ in Xri. It can be assumed that he indeed intends to indicate a voiced plosive. Meinhof uses a plosive $b$ for !Ora as well, contrasting it with Nama $w$.

For the purpose of interlinear glossing a tilde $(\sim)$ is used as boundary symbol to link reduplicated roots in causative constructions, and to mark PGNs that are normally spelt conjunctively with the preceding word, but are not grammatically part of it. In the wordlist the (disjunctively occurring) tilde represents the key word in an example.

The main lects are, in the wordlist, referred to by respective capitals in square brackets, if so: [D] Damara, [N] Nama, [K] !Ora, [X] Xri. While !Ora lexicon is not provided systematically, entries that were marked as !Ora by Snyman are marked with [K] (for Korana) in the present list, so as to point out the distinctiveness or similarity to Xri. As said, !Ora reflexes are not considered for rates of proximity. Cognates with an irregular consonantal correspondence to Khoekhoe are marked with an asterisk * in Xri. Cases where the depressor status of an initial Xri consonant does not correlate with the tonal melody of Khoekhoe are marked with a double asterisk **. The reader is reminded that this issue of depression does not apply to the melodies /43/ and /24/. For reasons of space only some select exemplifications are provided in the discussion, rather than exhaustive lists.

Xri voiced velar accompaniment $g \mathrm{X}$ and Khoekhoe "double low" melody / " `/

$\begin{array}{lll}\text { Gloss } & \text { Xri } & \text { Khoekhoe } \\ \text { divide } & \text { gloara, glora } & \text { Igörà } \\ \text { belch } & \text { g!ai } & \text { !gäì } \\ \text { groan } & \text { g!ae } & \text { !gäè } \\ \text { bull } & \text { glloop } & \text { \|göòb } \\ \text { wing } & \text { g\|labop } & \text { \|gäwòb } \\ \text { lean - bec. } & \text { głaba }[X],[K] & \text { łgäbá } \\ \text { mud } & \text { głoap }[X] & \text { fgöàb }\end{array}$

Counter examples

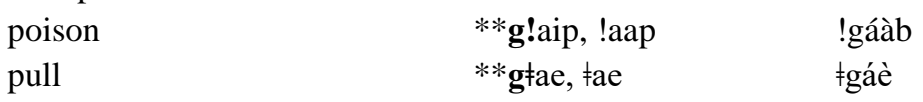

Of 20 instances three, or $15 \%$ are counter examples, where Khoekhoe has a /32/ melody instead of a /12/ melody, despite a depressor consonant in Xri. Of these three, however, two words were recorded with both voiced and voiceless clicks, suggesting a measure of uncertainty on the side of the consultants.

It should be kept in mind that words spelt with Xgin Khoekhoe can have either depressed or non-depressed melodies, as the clicks are mergers of the pretonogenetic voiced and voiceless accompaniments. Only comparative data can reveal irregularities.

Xri voiced velar accompaniment $\mathrm{gX}$ and Khoekhoe "low-rising" melody / " '/ 


\section{Gloss}

hip

twin

chin

trunk (of tree)

gargle

meat

lean - bec.

nose
Xri

glubup, Inuwup

lamglee-e

g!anni

g!aop

gllobo

g\|anni

głaba $[\mathrm{X}],[\mathrm{K}]$

głuip $[\mathrm{X}]$, głuis $[\mathrm{K}$

\section{Khoekhoe}

Igüwús

Igëéb

!gäńni/-s

!gäób

"göwópẻnám!nà̃à,

"göwópe"

\|gäńni

łgäwá

łgüís

Counter examples

boil $v . i$
press
dress $v$.
west
$|\hat{u}, * * g| \hat{u}$
** $\mathbf{g} \|$ âi
** głaełâ;łaełaa
**soregłaas

|gừù

|gàì

fgàèłgàà

sórès di łgàà̀lkháàb

Out of 19 pairs two to four $(11-21 \%)$ are counterexamples, with two instances displaying uncertainty in voicing of the click accompaniment.

Khoekhoe clicks with voiceless unaspirated releases, spelt $\mathrm{Xg}$, are not depressors, as they are devoiced mergers of the respective Xri and !Ora voiced velar accompaniment $g \mathrm{X}$ and the voiceless velar accompaniment simply spelt $\mathrm{X}$ here for Xri. Hence all melodies are found with the Khoekhoe X $g$ clicks.

It should be remembered that in Khoekhoe (obvious) depression only applies to the melodies /22/ and /32/; not to /24/ and /43/. ${ }^{14}$ In the database each of the 89 Xri words with a voicelessglottal accompaniment without exception has Khoekhoe cognates with one of the nondepressed melodies /43/, /24/, /32/ or /22/; e.g.

\begin{tabular}{|c|c|c|}
\hline Gloss & Xri & Khoekhoe \\
\hline brother & !âp & !gạáb \\
\hline enter & fâ & łgà̀à \\
\hline grass & lâp, lamp & |gànäb \\
\hline take shelter from & laa & |gáà. \\
\hline
\end{tabular}

It can thus be concluded that Xri is distinct from Khoekhoe, in that it has a pre-tonogenetic system where voicing still is distinctive and - assumedly - has not caused tonal depression. It seems to differ also from !Ora, for Beach (1938: 250) holds that in !Ora the "original $\mathbf{g}$ click-efflux seems to have become unvoiced $\mathbf{k}$ throughout". Despite of this neutralization he had not in !Ora observed tonogenetic transphonologisation to depressed melodies. The neutralisation of voicing with consequent tonogenesis is the most distinctive characteristic of the Khoekhoe dialect cluster that includes the Haillom and $\neq$ Aakhoe dialects, as opposed to !Ora and Xri.

\footnotetext{
${ }^{14} \mathrm{Cf}$. section 3.1 above. See also Haacke 2008 for a discussion.
} 
Xri clicks with voiceless glottal fricative release $X^{\prime} h$ and Khoekhoe clicks with delayed voiceless glottal fricative release $\mathrm{X} h$

Snyman writes the equivalent click release of the Khoekhoe delayed glottal fricative release $\mathrm{X} h \quad[\mathrm{X} \mathbf{h}]$ in Xri with an apostrophe signifying an "interruption", followed by a glottal fricative $h, v i z . \mathrm{X}^{\prime} \boldsymbol{h} ;$ e.g.

$\begin{array}{lll}\text { Gloss } & \text { Xri } & \text { Khoekhoe } \\ \text { bag } & \text { I'hoop } & \text { \|höób/s } \\ \text { basket } & \text { |'harup } & \text { |härùs } \\ \text { bee } & \text { !'habup } & \text { !häwúb } \\ \text { placenta } & \text { ł'hoos } & \text { łhöós }\end{array}$

He does not provide phonetic descriptions in his Xri field notes, quite understandably. But this makes the phonetic interpretation of his apostrophy in the click release $X^{\prime} \boldsymbol{h}$ a matter of concern, as he uses the apostrophe to indicate a glottal stop ['] in the glottal stop click release X', e.g. l'abib (aardvark), and in the velar affricate, e.g.kx'aa (drink). A consistent use of the apostrophe would thus let it represent a glottal stop also in the click release involving the glottal fricative $h$. The click followed would thus be a voiceless glottal affricate release. This is distinct from !Ora, where, according to Beach (1938:232) the release is an unvoiced glottal fricative like in Khoekhoe. Meinhof (1930: 149 et seq.) likewise does not record the glottal stop for Xri but simply the glottal fricative, as in !Ora or Khoekhoe.

Snyman's published materials may provide a lead to his method of phonetic transcription. In his Master's dissertation (Snyman 1970: 53) he describes the click accompaniment for !Xũ ' $\boldsymbol{h}$ as "laryngeal and interruption features" (italics added, W.H.) and he indeed renders it phonetically as a glottal stop, e.g. [₹’h]. In his subsequent doctoral thesis, however (Snyman 1975: 95-96, submitted in 1972, about the time when he did his fieldwork on Xri) he renders I'hand corresponding clicks phonetically as $[\mid \mathbf{h}]$. The macron signifies a pause or delayed articulation of the fricative, not a glottal closure. This latter interpretation of the apostrophe in the click release falls in line with !Ora and Khoekhoe and will be adopted here as appropriate.

The database contains 100 instantiations where Xri $\mathrm{X}^{\prime} \boldsymbol{h}$ corresponds to Khoekhoe X $\boldsymbol{h}$ [X $\mathbf{h}]$. Of these 100 only the following ten deviate aberrantly from this click correspondence:

Gloss
breathe strongly (sniff)
cat
wheat
cut (thong) spirally
land
pole
rainbow
message
bother
gather
spider (big black)

Xri
*|'ubi
*'ôas, l'hôas
*|'hû(n)!'horop
!'hari, *!xari
*!uup
*!'anap
*|'hôas / tuus !'anap
*łhôap
*n|'huuxa
|'hami, *xami
*|nuus

Khoekhoe
|hüwì
|höàs
!höròb
!härì
!hüúb
!hänàb
tüú!hànäb, làwï!hànäb
łhöàs/b
|hűú
|hảmí
|hùüs


Of the 100 instantiations with Xri X'h65 have one of the two depressed melodies in Khoekhoe. The other 35 melodies are of the two types not susceptible to depression (/24/, /43/), with a single exception:

winnow **!'haa !háà.

The delayed glottal fricative is a very consistent depressor in Khoekhoe. Of the 336 roots with a delayed glottal fricative click release used in Haacke (1999) !háà is one of only eight counter examples (1999: 62).

\section{Nasal click accompaniment $\mathrm{Xn}$}

The nasal accompaniment occurs unchanged in Xri, !Ora and Khoekhoe. It acts as depressor in Khoekhoe. Snyman's practice of writing $n$ before the click symbol has been changed here to the convention followed in Khoekhoe, viz. Xn, so as to facilitate comparison.

\section{Aspirated egressives}

According to Beach (1938: 253) "The older strong-voiced plosives $\mathbf{d h}$ and $\mathbf{g h}$ first became unvoiced plosives th and $\mathbf{k h}$. The th remained in Korana, except before the close front vowels $\mathbf{i}, \mathbf{i}$, and $\mathbf{e}$ where it became ts; it became ts in Nama before all vowels. The kh remained in Korana, but became kx in Nama".

\section{Xri aspirated alveolar plosive $t h$ and Khoekhoe aspirated alveolar affricative $t s$}

$T s$, according to Haacke (1999: 56) is an entirely consistent depressor in Khoekhoe. This is to be expected because of its "strong-voiced" origin in dh.

The regular correspondences that Beach has found for !Ora cannot be confirmed for the present Xri data, however. Xri fluctuates between the !Ora aspirated plosive th and the Khoekhoe aspirated affricate $t s$ (which Snyman spells as $t s h$, and once as $c s$ ). After the close front vowels $e$ and $i$ the only two instances in the Xri corpus - one with $e$, one with $i$ - appear with the affricate $t s h$, as they do in Khoekhoe and !Ora. The fluctuation of Xri seems to be symptomatic of its moribund state. On the other hand, it indicates that the consultants do not merely present borrowings from !Ora. Snyman has labeled elicitations with a ' $[\mathrm{K}]$ ' that, according to the opinion of his consultants, were !Ora versions. The following instances without exception have a depressed melody in Khoekhoe, if the melody is susceptible to depression.

Gloss
swim
dust
lick
sow
anus
hurt
melt $v . i$
pain $v$.
regret
wrong

\section{Xri}

tshâ;

tsharap, *tharap

*csaa, *thaa

tshoro

- $\quad$ (thoap [K])

*thûthû

tshuni, *thuni

tshû

* aaothuu (heartsore)

tshuu!aa (Griekwastad), thuu

\author{
Khoekhoe \\ tsa्àa \\ tsäráb \\ tsäá \\ tsöró \\ tsöás \\ tsüútsùù \\ tsünì \\ tsüù \\ tsüùuäłgáò (= feel sad) \\ tshüù
}


Front vowel $e$ :
day after tomorrow
!non\|âitsheep, \|'ari!âtsheep \|àrìkàmıtsèëb
yesterday
\|'aatshee, |l'arikamtsheep \|àrìkàmı̈tsèë

One exceptional pronunciation with a voiced fricative $[\mathrm{z}]$ before $\hat{\imath}$ is on record:

$$
\text { toe }- \text { big *zîp tsiìb/s }
$$

The following instances are words for which Khoekhoe cognates have tonal melodies (/24/, /43/) that are not susceptible to depression. They thus are not counterexamples to the $100 \%$ depressor effect of $t s$ in Khoekhoe. The occurrences of $t h$ and $t s h$ in the Xri reflexes cannot be associated with specific tonal melodies in Khoekhoe but seem to be arbitrary fluctuations.

\begin{tabular}{|c|c|c|}
\hline boil $n$. & tshuip & tsùîs \\
\hline grey & *thaothao & tsäótsáò (= ashen) \\
\hline grope & *thâthâ & tsa̋nánä> tsăánä \\
\hline night & tshuxuba, *thuxuba & tsuxub [tsùüxúùp] \\
\hline sexually excited - be & *thâ & cf. tsàa $(=$ feel, taste) \\
\hline soft & *thamsa & tsàürä, tsàmsä \\
\hline string, rope & *thurip & tsűúrïb \\
\hline taste & tshâ & tsàă \\
\hline thumb & - (kâitsîs [K]) & käítsîl||güübës \\
\hline tonight & tshuxuba & [tsùüxúùbä] \\
\hline
\end{tabular}

\section{Front vowel $i$ :}

and

tshii

tsî/tsi [tsiìn, tsiì]

\section{Xri aspirated velar plosive $\boldsymbol{k} \boldsymbol{h}$ and Khoekhoe aspirated velar plosive $\boldsymbol{k} \boldsymbol{h}$}

As both !Ora and Khoekhoe have retained an aspirated velar plosive $k h$, it is not surprising that Xrilikewise has an aspirated velar plosive $k h$ as cognate; e.g.

$\begin{array}{lll}\text { Gloss } & \text { Xri } & \text { Khoekhoe } \\ \text { light (fire) } & \text { khau } & \text { khäù v.t. } \\ \text { burn } v . i & \text { khabu } & \text { khäú } v . i \\ \text { lift up } & \text { uukhâi } & \text { ùükhäí } \\ \text { man } & \text { khoep } & \text { khöèb }\end{array}$

Note that the intransitive Khoekhoe verb khäú is derived from the transitive khäù by means of the /13/ melody. This process must also have existed in !Ora where the "low-mid falling" melody (Beach 1938: 248) has been the etymon of Khoekhoe /22/ and /13/. ${ }^{15}$ We have no information about the possible existence of this process in Xri, but note that in the above case the intransitive khabu has the canonic CVCV structure, while the transitive khau has elided C2.

\footnotetext{
15 See Haacke 1999: 74.
} 
Only two of the 18 cognates to Khoekhoe $k h$ are recorded for Xri with consonants different from $k h$ :
$\operatorname{dig}$
khao, *kxau
khào
skin $n$.
*kxhoop
khòőb.

Beach's claim that "the kh remained in Korana, but became kx in Nama" (Beach 1938: 253) cannot be confirmed. At least today the affricative pronunciation of the velar certainly is much rarer in Khoekhoe than the aspirated pronunciation. (In especially the Sesfontein dialects of the Namidama (Namib-Damara) $k h$ is pronounced as fricative $x, e . g$. khòöb (skin) $>$ xööb.)

\section{Xri voiced plosives $b, d$ and $g$}

Voicing in initial egressive plosives of Xri corresponds to depression in Khoekhoe, while their unvoiced counterparts $p, t$ and $k$ correlate with non-depressed cognates in Khoekhoe, just as in !Ora. Beach has no evidence for $b$ in !Ora, simply because bilabial plosives are comparatively rare in $\mathrm{C} 1$ of Khoe radicals.

The reader is reminded that in Khoekhoe the symbols $p, t, k$ on the one hand, and $b, d, g$ on the other do not reflect voicing but higher and lower tonal melodies instead, as all plosives are devoiced (see above, 3.1).

\begin{tabular}{|c|c|c|}
\hline Gloss & Xri & Khoekhoe \\
\hline take away & uubee & ùübëé \\
\hline Tswana (= goat) & Piris/p, Parip & Pìrís/b ${ }^{16}$ \\
\hline tear $v . i$. & doa & döá \\
\hline tinder box & doros & dörós \\
\hline spotted & too & tòő \\
\hline swallow & tom & tóm \\
\hline sheep & guus & güús \\
\hline stupid & gâre & gạaárë, gạà \\
\hline shade & karap & kàräb (coolness of afternoon) \\
\hline bead & karap & kärás \\
\hline speak & koba & gòwà̀ $^{17}$ (= argue) \\
\hline
\end{tabular}

Note the case where with a voiced plosive in Xri, Nama did not undergo depression, but the geographically more removed Damara dialects did:
at
daba
táwà $[\mathrm{N}]$; täwà $[\mathrm{D}]$.

For the sake of simplification only the spelling with tis used for tawa.

\footnotetext{
${ }^{16}$ Meinhof (1930: 81) renders 'goat' as biri- in !Ora. But then he renders the bilabial plosive only as $b$, never as $p$. In "Nama" he likewise lists "beri-b" with a voiced plosive, which it does not have.

${ }^{17}$ The reader is reminded that $/$ " $/$ is a non-depressed melody; hence the voiceless plosive $k$ in the Xri cognate. It is merely an orthographic convention that words in Khoekhoe with a / $" /$ melody are spelt with a voiced plosive to identify them as words with one of the lower melodies.
} 
In intervocalic position the bilabial consonant of Khoekhoe appears mostly as dentilabial fricative [v], but it can also be pronounced as bilabial plosive [b] (especially in Damara) or less commonly as bilabial fricative $[\beta]$; i.e. there is a tendency to lenition, hence fricativization. The standardized spelling with the letter $w$ for Khoekhoe is neutral/non-committal with regard to tone, as $p$ and $b$ can intervocalically also be used instead to indicate a higher or lower melody. While no explicit information is available it must by default be assumed that Snyman's consistent spelling with the plosive $b$ indeed signifies an intervovalic plosive consonant in Xri. The possibility of some degree of lenition can, however, not be excluded for Xri. Lenition, after all, led to the formation of roots with juxtaposed identical or non-identical vowels through complete elision of the intervocalic consonant in Khoekhoe languages, generating so-called "long vowels" and "diphthongs".

3.2 Equivalents of Khoekhoe non-depressor consonants in Xri Khoekhoe has two nondepressor click releases: the glottal stop $\mathrm{X}^{\prime}$ (spelt with the click symbol only) and the aspirated or affricated uvular release $\mathrm{X} k h$.

\section{Xri glottalic affricate release $\mathrm{X} \boldsymbol{x}^{\prime}$ or glottal stop release $\mathrm{X}^{\prime}$ and Khoekhoe glottal stop release $\mathbf{X}^{\prime}$}

The Khoekhoe glottal stop release $X^{\prime}$ has two cognate releases in Xri. While one is identical to that of Khoekhoe, viz. a glottal stop release (spelt here as $\mathrm{X}^{\prime}$ for Xri), the other is a glottalic affricate $\mathrm{X} \boldsymbol{x}^{\prime}$. Both variants appear in !Ora as well (cf. Beach 1938: 232 et seq.). The occurrence does not appear to be contextually determined, and occasionally both variants are on record for a word. Beach (1938: 233) is of the opinion that $\mathrm{X}^{\prime}$ is in the process of being replaced by $\mathrm{X}^{\prime}$ as in Khoekhoe. Releases with the glottal stop appear to be more dominant in the Xri data, and occasionally Snyman has recorded contrasting variants from !Ora with the glottalised fricative. At this stage it can not be determined from these releases whether the Xri consultants were under any predominant influence of either !Ora or Nama, but - as the following !Ora cognates from Meinhof 1930 and Engelbrecht 1928 show - the Xri click releases are identical to those of !Ora in most cases, and the question arises to what extent the "Xri" of the 1970s actually is a version of !Ora. ${ }^{18}$ A comprehensive investigation cannot be undertaken here for reasons of space.

\begin{tabular}{|c|c|c|c|}
\hline Gloss & Xri (Snyman) & Khoekhoe & !Ora \\
\hline bald head & l'oodanab, & lóòdänáb & cf. I'oo|xaa (naked) \\
\hline breathe & l'om & lòm & cf. |'umma (breath) \\
\hline full & |'oasa, |x'oasa & lòàsä & Ikx'oa full; cf. l'oa (fill) \\
\hline sharp & |'aa, |x'aa & láà & $\begin{array}{l}\text { Ikx'aa } \\
\text { cf. I'aal'aa (sharpen) }\end{array}$ \\
\hline fear & !'ao & !áò & $\begin{array}{l}\text { !'au fear; !'aosa (be } \\
\text { frightened) }\end{array}$ \\
\hline fish & l'aup & \|àùb & \|aub; \|’aub (< Engelbr.) \\
\hline cough & \|'ui & \|úì & \|’ui \\
\hline blunt & f'ubu & fùwù; fùù $\mathrm{D}$ & f’ubu \\
\hline peep & f'ui & łùĭ & ‡’ū̄ (look at closely) \\
\hline
\end{tabular}

\footnotetext{
${ }^{18}$ To facilitate comparison Meinhof's orthography has been transliterated according to the same conventions as Snyman's. His renderings have been translated from German.
} 
The following are the instances found of Khoekhoe tonological counter examples (i.e. with depressed melodies) or irregular click correspondences:

\begin{tabular}{|c|c|c|c|}
\hline dish & !'ores & !örés & !'oreb, !'orekua (Engelbr.) \\
\hline back & \|'âp X, (\|x'âp [K]) & \|äáb & $\| \mathbf{k x} \mathbf{x}^{\mathrm{a} b}$ \\
\hline few, little & !x'aro & !gäró & - \\
\hline porridge & !'x'ammi & $\begin{array}{l}\text { !khámmi [D] } \\
\text { (= uintjie broth) }\end{array}$ & !kx'amma \\
\hline bladder & $\| \mathbf{x}^{\prime}$ urup & \|khùrùs & - \\
\hline
\end{tabular}

\section{Xri fricative release $X \boldsymbol{x}$ and Khoekhoe aspirated or affricated uvular release $X \boldsymbol{k} \boldsymbol{h}$}

Beach (1938: 231) describes the relevant efflux of !Ora as "unvoiced velar affricative" release, but he spells it simply as Xx . Snyman adheres to the same orthographic practice, but left no information about the pronunciation. The click correspondences between Xri and Khoekhhoe are fairly regular; e.g.

\begin{tabular}{|c|c|c|}
\hline Gloss & Xri & Khoekhoe \\
\hline absent & |xai & |khài" \\
\hline arrest & !xoo & !khőó \\
\hline blanket & !xons & $\begin{array}{l}\text { !khòǹs/!khèns, (patchwork } \\
\text { blanket) }\end{array}$ \\
\hline $\begin{array}{l}\text { Acacia karroo } \\
\text { brain }\end{array}$ & 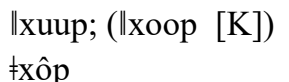 & $\begin{array}{l}\| \text { khùüs } \\
\neq \text { khùùb/s }\end{array}$ \\
\hline
\end{tabular}

The following irregularities (involving Khoekhoe $\mathrm{X} k \mathrm{~h}$ ) constitute some $6 \%$ of the cognates, the erratic nature of which seems to be indicative of the moribund state of Xri:

\begin{tabular}{|c|c|c|}
\hline tremble & I'huu!naa, |xuu!naa & |khùü \\
\hline elephant shrew & $\| x a u p / s$ & !khàü(łgüí)b \\
\hline fold & !'hon & !khőń \\
\hline moon - new & !hae\|xâs & !khàèlkhàaäb \\
\hline cf. darkness & !xaep & !khàèb \\
\hline pierce & $\mathbf{l h}^{\mathbf{x}}$ aa $(?)$, !xaanaru & !khàä \\
\hline porridge & !x'ammi & !khámmi $[\mathrm{D}]$ (= uintjie broth) \\
\hline snaring place & !'huis & !khuis (?) \\
\hline stupid & g!ookhoe, g!ooke & !khựúkë [D] \\
\hline bladder & $\| \mathbf{x}^{\prime}$ urup & $\|$ khùrùs \\
\hline thorn & \|'huup, \|xuup & \|khùüb \\
\hline Xhosa & ॥Hoosap & \|Khóòsäb \\
\hline small & fxari, $\neq$ hhari & łkhàri" \\
\hline
\end{tabular}

3.3 Xri correlates to the Khoekhoe glottal plosive onset [?]In line with the canonical root structure of Khoe languages $\mathbf{C 1 V}(\mathrm{C} 2) \mathrm{V}$, roots spelt with a vowel as initial sound in Khoekhoe phonetically actually commence with a glottal stop ?as $\mathrm{C} 1$, e.g. 


$\begin{array}{lll}\text { Gloss } & \text { Xri } & \text { Khoekhoe } \\ \text { drink } & \bar{a} & \text { ['áà] C1VV } \\ \operatorname{dog} & \text { arib } & \text { ['äríp] C1VC2V. }\end{array}$

The presence of an onset consonant was beyond doubt perceptible in the respective !Ora cognates: viz. $\boldsymbol{k} \boldsymbol{x}^{\prime} a a$ and $\boldsymbol{k} \boldsymbol{x}^{\prime}$ ari The glottal stop is not articulated very distinctly in Khoekhoe, though, and presumably also not in Xri. Snyman follows the Khoekhoe orthographic practice and commences a root with a vowel in the absence of $k x^{\prime}$. It is not clear whether he was aware of the root-initial glottal stop as phoneme in Khoekhoe. Beach (1938: 188 and 251) contrasts initial ' and $k x^{\text {? }}$ in !Ora, but, although he does acknowledge the occurrence of ? as "independent phoneme" in Nama, dwells more on its phonetic capriciousness. The canonic existence of it as phoneme in $\mathrm{C} 1$ position of Khoekhoe roots was pointed out in Haacke 1999: 10.

In the Xri data no consistency exists, as the initial consonants fluctuate between either a glottalised velar affricate $k x^{\prime}$ or a glottal stop ?. Meinhof (1930: 146) found the same fluctuation between "' " and " $\boldsymbol{k}^{\prime}$ " in Xri.

Beach's claim (1938: 251) that in Khoekhoe ' goes with the non-depressed melodies /32/ and /22/ was refuted in Haacke (1999: 56-58) with numerous counter examples, as ' occurs with all six main melodies. This is not surprising, as the glottal stop ? of Khoekhoe is intrinsically voiceless, but can be expected to be a historical merger. It is thus interesting that in Xri instantiations commencing in /32/ and /22/ consistently - one alternative aside - occur with $k x^{\prime}$, while no instantiations (happen to?) occur with their depressed counterpart melodies /12/ and /13/:

\section{Gloss}

/22/

alive

raw, cf. rude

\section{/32/}

boy

drink

drown

house

look back

louse

man - young

thief

\section{/13/}

e.g. bow

\section{Xri}

kx'ûi

kx'oara

kx'aoloodap,

*aoloodap

kx'aa

kx'aall'oo

kx'ommi

!abakx'oa

kx'urip

kx'arop

|x'âkx'aop

\section{Khoekhoe}

ùìä

òrà

àòrë |góàròb/|góòròb

$$
</ 32 /+4
$$

áà

ààlőó </32/+/43/

óms/-mi

kòő-óà

úrìb

áàxäròb; cf. áòb

lăa-àöb

\section{/12/}

e.g. consecrate

khäì 
The data suggests that in Xri $k x^{\prime}$ and ' were separate phonemes that merged in Khoekhoe?. This distinction does not pertain to !Ora, however, according to Meinhof's wordlist. In !Ora words commencing with a glottal stop do exist, but are decidedly in the minority.

In the two Khoekhoe melodies not (obviously) susceptible to depression, /24/ and /43/, both consonant onsets occur in the Xri cognates, seemingly at random: ${ }^{19}$ Note the articulatory contradictions below between \|oekx'am and maa-am, !'ere-am, łanam. The high degree of agreement, some $83 \%$, between the initial onset of Xri and !Ora nevertheless is considerable.

/24/, /43/

\begin{tabular}{|c|c|c|c|}
\hline Gloss & Xri & Khoekhoe & $\begin{array}{l}\text { !Ora } \\
\text { (Meinhof) }\end{array}$ \\
\hline aloe & $\begin{array}{l}\text { kx'aukorap, aukx'orap, } \\
\text { kx'auxuukorap; } \\
(\text { kx'ausaxuup }[\mathrm{K}] \text { ) }\end{array}$ & àükőréb & $\begin{array}{l}? \\
\text { kx'au... }\end{array}$ \\
\hline allow & maa-am & mäà-ám & maakx'am \\
\hline ambush & \|oekx'am & |gòë-ãḿ 4343 & \|oelkx'am \\
\hline close & $* \neq a n a m\left[\ddagger a n^{2} a m\right]$ & łgäńám [łanªm] & fankx'am \\
\hline answer & $\begin{array}{l}\text { !'ere-am [!?ere'am], } \\
\text { !'are-am, łhoakx'am, }\end{array}$ & !érèám $\left[!^{?} \mathrm{ere}^{(\mathrm{)})} \mathrm{am}\right]$; & $\begin{array}{l}\text { †hoakx'am } \\
\text { fhoallkx'am }\end{array}$ \\
\hline & $\begin{array}{l}\text { oe-am } \\
\ddagger \text { łhoa'ama }\end{array}$ & òè-ám; oetsi $[\mathrm{D}][=\mathrm{concu}$ & \\
\hline at the end & kx'aip daba & lunis tawa & (kx'ai) \\
\hline beard & kx'ail'hom (-ku) & |höò-äḿs cf. äís (face) & $?$ \\
\hline before, in front & ai!'â; $\quad$ (kx'ai!'â [K]) & ä!!àà & kx'ai \\
\hline bitter & kx'au & àü & $\mathbf{k x} x^{\prime} a u$ \\
\hline face & kx'aip & äls & kx'aib \\
\hline give & $\mathrm{au}$ & äú & 'au \\
\hline give birth & ôa & Q̀ä (of: anim.) & $?$ \\
\hline gums & arika & àrïb & $?$ \\
\hline hole & kx'aas, aap & äás & 'aab \\
\hline kidney fat & âup & àuün & $?$ \\
\hline lift up & uukhâi & ùükha्aí & 'uukhâisi \\
\hline lip & kx'ammi & äḿ\|gäúb & kx'amkx'aib \\
\hline liver & kx'âip & åaís & kx'âib \\
\hline maiden & oaxais & őáxáès & 'oaxais \\
\hline milk - curdled & âudaip & à̀üdàìb & 'âubîb \\
\hline on & ai & áì & kx'ai \\
\hline pick up & ûkhâi & ùűkha्aí & 'ukhâsi \\
\hline pit (of stomach) & kx'aił'am & å̃íłàms & $?$ \\
\hline roast & kx'am & àm & kx'am \\
\hline rob & uul'hana & ùülhäná & cf. 'uu- \\
\hline search & kx'ôa, ôa & ōá & kx'ôa \\
\hline
\end{tabular}

\footnotetext{
${ }^{19}$ This statement needs further verification, though, as it has been shown (Haacke 2008) that there exists also a depressed melody /24/ next to the non-depressed one. This depressed melody is not considered in the present investigation, as instances are rare and difficult to detect without comparative data.
} 


$\begin{array}{llll}\text { sweat } & \text { aosen } & \text { áòsèn, áòsèǹ } & \text { 'aosen, 'ausen } \\ \text { take } & \text { uu } & \text { űú } & \text { 'uu } \\ \text { take away } & \text { uubee } & \text { ùübëé } & \text { cf. 'uu- } \\ \text { trinket } & \text { anis, ainis } & \text { (cf. àn'́ = decorate) } & ? \\ \text { truth } & \mathbf{k x} \text { 'amap } & \text { ämäb <ämmäb } & \text { kx'amab }\end{array}$

See also footnote 25 for the treatment of compounds.

3.4 Nasalised vowels with PGNSnyman has recorded a phenomenon for Xri thatneither Beach nor Meinhof nor Engelbrecht recorded for !Ora, and that seems to be another indication of an authentic Xri lect. When roots with nasalized vowels are followed by a third person masculine singular PGN $p$, then the nasalization of the vowel may disappear and become a prenasalisation of the PGN. ${ }^{20}$ It would appear that Snyman has used a narrow phonetic transcription to demonstrate this phonetic detail, as shown below:

$\begin{array}{lll}\text { Gloss } & \text { Xri } & \text { Khoekhoe } \\ \text { grass } & \text { lâp, lamp } & \text { |gà̀ăb }\end{array}$

Prenasalisation is triggered mainly by the bilabial PGN $-b$, but occasionally also by the velar onset of the third person masculine plural PGN $-k u$. It does not seem to appear with other PGNs or consonants; cf.

\begin{tabular}{|c|c|c|}
\hline horn & $\|$ namp but $\|$ nâku & \|näàb \\
\hline thief & |x'amp, |x'âkx'aop & |åàà-àöb \\
\hline tooth & $\| \hat{\mathbf{u} p}$ & 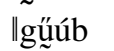 \\
\hline teeth & $\begin{array}{l}\text { \#ômp//ônku//'angku'21 } \\
\text { \|ungku }\end{array}$ & \|gựúgu \\
\hline
\end{tabular}

The following instances of $*_{-} p$ occur in the vocabulary:

\begin{tabular}{|c|c|c|}
\hline Gloss & Xri & Khoekhoe \\
\hline arm & f'hamp & fhàaäb (= forearm) \\
\hline December & Kaitseedi \|âmp & $\begin{array}{l}\text { Hôasoreb (cf. \|kháà }= \\
\text { month) }\end{array}$ \\
\hline eyebrow & $\operatorname{lnamp}$ & lámmèb; lámmïb [N] \\
\hline head & $\begin{array}{l}\text { bii-/baa-/bee!'amp, } \\
\text { (bii!'âkwa K) }\end{array}$ & dänáb \\
\hline krantz & fâp, famp, f'amp & łgàa \\
\hline mountain & 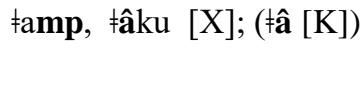 & $\begin{array}{l}\text { !hömmi (łgàä } \mathrm{b}=\text { rock } \\
\text { face) }\end{array}$ \\
\hline
\end{tabular}

\footnotetext{
${ }^{20}$ While Snyman's rendering of the masculine PGN as voiceless $-p$ is phonetically correct, this PGN in (unreleased) word-final position is also voiceless in Khoekhoe. It is spelt with a $-b$, though, as it is voiced, when succeeded by a vowel, especially the oblique marker $-a$ in, e.g., aoba.

${ }^{21}$ Obviously there is an inconsistency in the transcription of \|ônkuand \|'angku, one with nasal vowel and alveolar nasal, the other with oral vowel and velar nasal. What is important is that prenasalization of a sort appears before the PGN $k u$.
} 


\begin{tabular}{|c|c|c|}
\hline thief & |x'amp, |x'âkx'aop & lạ́à-àöb \\
\hline August & 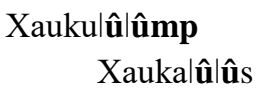 & Áòlkhùümüúúlkhà̀äb \\
\hline ear & \|nâump & ( cf. \|nã्ú = hear) \\
\hline hair & l'ump, |'ômp, l'ûku & lừùb \\
\hline
\end{tabular}

It is noteable that there occasionally is a discrepancy between oral and nasalised vowels of Xri and Khoekhoe: e.g.

\begin{tabular}{|c|c|}
\hline armpit & gam!naap \\
\hline crockery & khoaxuuku \\
\hline dress $v$. & 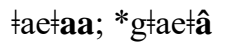 \\
\hline
\end{tabular}

Beach (1938: 187) already observes that "many Korana roots differ from Nama roots by the substitution of one sound for another (e.g. a nasal vowel for an oral or vice versa, a vowel combination for another, one click for another, etc.)." As nasalised vowels in Khoe languages have become distinctive after the elision of an intervocalic nasal, viz. ${ }^{*} \mathrm{CVNV}>\mathrm{C} \tilde{\mathrm{V} N} \tilde{\mathrm{V}}>\mathrm{C} \tilde{\mathrm{V}}$ (cf. Haacke 1999: 11), it implies that any discrepancy of nasalisation between contemporary lects must be due to an etymological irregularity in one or the other of the lects. As said before, it can be assumed that discrepancies such as in nasalisation, and especially also discrepancies in clicks, are more likely to have occurred in the moribund Xri and !Ora rather than in Khoekhoe because of the comparatively more deteriorated competency of the speakers.

\section{Miscellaneous morphological observations}

From the sporadic examples that Snyman has included in his word list it can be gleaned that Xri, like !Ora, uses $\boldsymbol{n} a$ for the present continuous aspect marker, instead of Khoekhoe $\boldsymbol{r} a$ or $\boldsymbol{t} a$; e.g.

\begin{tabular}{lllllllll} 
& Xri & & \multicolumn{9}{c}{ Khoekhoe } \\
'I am looking at the light' & mû & $r$ & na & !naap & !nâb-a & ta & ra & koo. \\
& See & I & PR & light & light-OBL & I & PR & look.at
\end{tabular}

While !Ora uses the same diminutive suffix for nouns as Khoekhoe, viz. -ro, Xri uses - $d a$.
fountain
$\mid x^{\prime} a u s$, I'audas
làüs, |àüròs.

According to Snyman's examples Xri seems to omit the oblique case marker - $a$ for the object NP even more consistently than !Ora (cf. Meinhof 1930 in Haacke 2013: 341); e.g.

\begin{tabular}{|c|c|c|c|c|c|}
\hline Xri: & $\begin{array}{l}\text { Hee } \\
\text { This }\end{array}$ & $\begin{array}{l}\text { |x'urip- } \emptyset \\
\text { iron- } \varnothing\end{array}$ & $\begin{array}{l}i r \\
\mathrm{I}\end{array}$ & $\begin{array}{l}n a \\
\text { PR }\end{array}$ & $\begin{array}{l}g\|o b a \sim g\| o b a \\
\text { bend CAUS }\end{array}$ \\
\hline Khoekhoe: & $\begin{array}{l}\text { Nee } \\
\text { this }\end{array}$ & $\begin{array}{l}\text { |urib-a } \\
\text { iron-OBL }\end{array}$ & $\begin{array}{l}t a \\
\mathrm{I}\end{array}$ & $\begin{array}{l}g e \\
\text { IND }\end{array}$ & $\begin{array}{ll}\text { ra } & \text { !hoa } \sim \text { !hoa } . \\
\text { PR }^{22} & \text { bend CAUS }\end{array}$ \\
\hline
\end{tabular}

\footnotetext{
${ }^{22}$ For category labels used in interlinearization see Abbreviations below.
} 
'I bend this iron'

The oblique case apparently is also not used with postpositions that use it in Khoekhoe, like $x u$ (from), e.g.

\begin{tabular}{|c|c|c|c|c|c|c|}
\hline Xri: & $\begin{array}{l}\text { Hee } \\
\text { this }\end{array}$ & $\begin{array}{l}\text { !khaip- } \varnothing \\
\text { place- } \emptyset\end{array}$ & $\begin{array}{l}x u \\
\text { from }\end{array}$ & $\begin{array}{l}r \\
\mathrm{I}\end{array}$ & $\begin{array}{l}n a \\
\text { PR }\end{array}$ & $\begin{array}{l}\text { doe. } \\
\text { move }\end{array}$ \\
\hline Khoekhoe: & $\begin{array}{l}\text { Nee } \\
\text { this }\end{array}$ & $\begin{array}{l}\text { !khais-a } \\
\text { place-OBL }\end{array}$ & $\begin{array}{l}\text { ta } \\
\mathrm{I}\end{array}$ & $\begin{array}{l}g e \\
\text { IND }\end{array}$ & $\begin{array}{l}r a \\
\text { PR }\end{array}$ & $\begin{array}{l}\text { dоехии. } \\
\text { move.from }\end{array}$ \\
\hline / & $\begin{array}{l}\text { Nee } \\
\text { this }\end{array}$ & $\begin{array}{l}\text { !khais-a } \\
\text { place-OBL }\end{array}$ & $\begin{array}{l}x u \\
\text { from }\end{array}$ & $\begin{array}{l}\text { ta } \\
\mathrm{I}\end{array}$ & $\begin{array}{l}g e \\
\text { IND }\end{array}$ & $\begin{array}{ll}\text { ra } & \text { doe. } \\
\text { PR } & \text { move }\end{array}$ \\
\hline
\end{tabular}

Xri also shares with !Ora the distinction between a masculine and a feminine PGN marker for the first person singular. In Khoekhoe the older forms have become neutralised into one form that is non-specific for gender:

$\begin{array}{lll}\text { Xri } & \text { masculine ir }(r) & \text { feminine } t a \\ \text { !Ora } & \text { masculine ir }(r) & \text { feminine } t a^{23} \\ \text { Khoekhoe } & \text { masculine/feminine } t a & \end{array}$

Regrettably data on the other PGN markers and on object concords are not available in the Xri examples.

Xri appears to use the indicative sentence type marker ge/ke only rarely. It is regularly used in main indicative sentences in Namibian Khoekhoe. In !Ora too the indicative marker tje is omitted more readily than in Khoekhoe. Witzlack-Makarevich (2006) has demonstrated that in the Khoekhoe of the Nama of the Northen Cape this indicative marker is also used less frequently than in standard Namibian Khoekhoe.

\section{Conclusion}

Snyman's vocabulary of Xri with over 1100 entries (transcribed from his cards) provides the most substantial evidence available that a Xri lect has indeed existed, and could be traced into the $20^{\text {th }}$ century despite the fact that by the $19^{\text {th }}$ century the ethnic communities identified as Xri or even Xrixri had virtually disappeared. As said, the data reveals a lexical proximity to Khoekhoe of $69 \%$. While this percentage clearly accommodates Xri as a lect in the Khoekhoe dialect continuum, the $31 \%$ difference to Khoekhoe suggests that the consultants interviewed in the 1970s did not speak a lect that was unduly influenced by their former or present Nama neighbours. The rate of cognation between Xri and !Ora appears to be particularly high (a systematic comparison was not undertaken here). But the prenasalization of the PGNs $-p$ and $-k u$ appears to be a distinctive characteristic of Xri that sets it apart as lect. The elicitations also show that the consultants were not merely repeating 
!Ora lexicon, as Snyman frequently has contrasted Xri with contemporary !Ora cognates. It can be assumed that the Xri consultants had rejected these words as being not their own but !Ora.

Haacke (2016) has investigated the lexical proximity of $17^{\text {th }}$ Century Cape Khoekhoe as compiled in vocabularies by Johannes Grevenbroeck, to !Ora according to Meinhof (1930) and Engelbrecht (1928) and present-day Khoekhoe (Haacke \& Eiseb 2002). It was found that Cape Khoekhoe has a rate of cognation of $69 \%$ to both !Ora and Khoekhoe, while there is a rate of $80 \%$ between !Ora and Khoekhoe. If the rate of cognation of $69 \%$ of Xri to Khoekhoe may be compared to those figures, albeit they quite different data bases, then it may be concluded that Xri has a greater lexical distance to Khoekhoe than !Ora has.

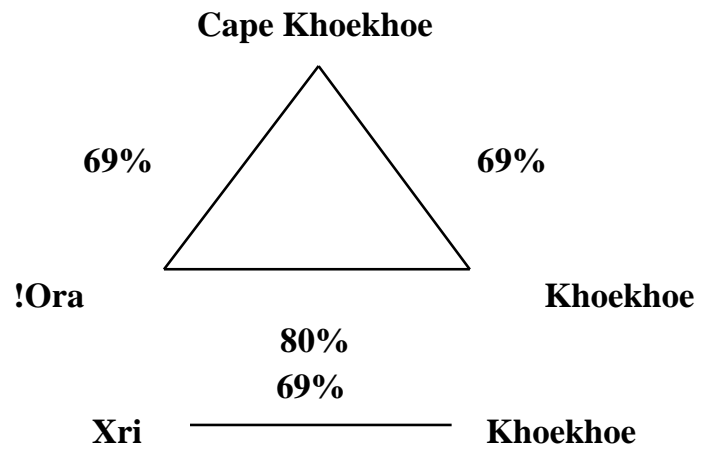


Appendix: Word List ${ }^{24}$

Gloss

\section{A}

\begin{tabular}{|c|c|}
\hline aardvark & l'abip \\
\hline & głooxommi $[\mathrm{K}]$ \\
\hline abomasum/(lang pens) & |x'aras \\
\hline abound with & |x'oasa \\
\hline absent & |xai \\
\hline Acaciaheteracantha & !oop \\
\hline Acacia karroo & $\|$ xoop $\quad[\mathrm{K}] ; \|$ xuup \\
\hline accustomed & !'ôi, fûi \\
\hline adam's apple, larynx & !'hores [K] \\
\hline admonish & |x'ai, |x'ae, ||x'ae \\
\hline afterbirth, placenta & f'hoos \\
\hline afternoon & !'uiba, !'uip \\
\hline again & $\begin{array}{l}\text { !'oe } \\
\text { ॥xaba }\end{array}$ \\
\hline aged & kaira, kaida \\
\hline alive & kx'ûi \\
\hline all & hoa, (wa), \|naa \\
\hline allow & $*$ maa-am ${ }^{25}$ \\
\hline aloe & $\begin{array}{l}\text { kx'aukorap, *aukx'orap, } \\
\text { kx'auxuukorap; } \\
\text { kx'ausaxuup }[\mathrm{K}]\end{array}$ \\
\hline alone & |uri; lona $[\mathrm{K}]$ \\
\hline always & \|naa \|aep \\
\hline ambush & \|oekx'am \\
\hline and & tshii, $\hat{\imath}$ \\
\hline angry (be) & $\begin{array}{l}\text { \|'aixa, } \\
\text { "'ani }\end{array}$ \\
\hline
\end{tabular}

Khoekhoe

Rating

|khùwüb, |gàilòb $\quad 0$

láräs 4

lòàsä 4

|khà" 4

!gòòs [= A.hebeclada $] \quad 4$

\|khùüs 4

\|näét" 0

döm̀!khòms [N], dömóòrös [D] 0

\|nả má 0

†höós (= afterbirth of animal) 4

!úìb [N]; !úiàb $[\mathrm{D}]$ (= twilight) 4

kàräb [D]

!oe (= bec. evening $[\mathrm{N}]$ )

\|khàwä

4

láàxùü-ämmé [N]

kälrà

ùisä 3

höá 4

mäà-ám 2

kőréb; àűkőréb $[\mathrm{N}]$

Igùr" 4

höálláè 0

\|gòë-a̋ḿ 4

tsî/tsi [tsiì, tsiil ]

\|àìxä 4

\|ámì

Bettis ge ti !oagu ra laixa.

Betty IND ART opposite PR angry

Betty IND me angry

'Betty is angry with me'

\footnotetext{
${ }^{24}$ See Section 3 above for the significance of the numerical ratings. Xri example sentences in italics are supplied by Snyman and have been interlinearised here. Khoekhoe equivalents were provided by Eliphas Eiseb.

${ }^{25}$ A missing glottalised velar affricate $k x^{\prime}$ or glottal stop ? in the subsequent root of Xri compounds, e.g. with $a m$ or $-a i$, is assessed as 2 (phonological diversion) in this list. Such words could arguably also be assessed as full cognates, as the phonetic difference is minimal.
} 


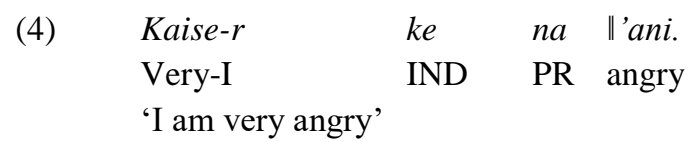

\begin{tabular}{|c|c|c|}
\hline ankle & !orop & !gòròs \\
\hline ankle-bone & !nooxoop & !gạ̋ùxäs \\
\hline announce & f'anf'an & fànłàn̈ \\
\hline another & Inî, Inâi & Inî [|nì̄'] \\
\hline different, other & |xara & |khàrà \\
\hline answer & $\begin{array}{l}\text { *!'ere-am, !'are-am, } \\
\text { łhoakx'am }\end{array}$ & !érèám [!?ere’am] \\
\hline & *oe-am & òè-ám; oetsi $[\mathrm{D}]$ (= concur) \\
\hline ant & $\begin{array}{l}\text { fuburup; } \\
\text { fomirop }\end{array}$ & łgùwùrüb; łgòwèrüb [D] \\
\hline anus & thoap $[\mathrm{K}]$ & tsoas \\
\hline applicative suffix & -ba & -ba \\
\hline
\end{tabular}

(5) \|'Ama- -i uи-haa-ba

\|Gam-e uu-haa-ba te! water- $\varnothing$ take-come-APPL water-OBL take-come-APPL me

'Bring me water!'

\begin{tabular}{|c|c|c|}
\hline $\operatorname{arm}$ & ł'hamp & fhàaäb $(=$ forearm $)$ \\
\hline arm - right & ‡'hanul|'ôap & àm\|̀äb \\
\hline armpit & gam!naap & gäḿn!náàs \\
\hline arrest & !xoo & !khőó \\
\hline
\end{tabular}

(6) !Xoo tsi-r na, ti birs its ko ko \x'aa labako daba. arrest you-I PR mygoat you REC ? steal police-OBL at 'I arrest you, you have stolen my goat at the police (station)'

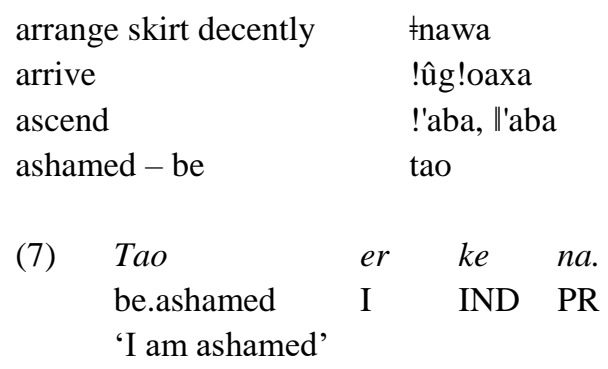

\begin{tabular}{|c|c|c|}
\hline askew & $\mathrm{g} \|$ oa, łuiłnam xoara & \|ärésè \\
\hline assemble & l'hao & |hàö \\
\hline at & daba & táwà $[\mathrm{N}]$; täwà $[\mathrm{D}]$ \\
\hline at the end & kx'aip daba & lunis tawa \\
\hline August & Xaukulûlûmp & Áò\|khùümüưulkhàaäb \\
\hline & Xaukalûlûs & \\
\hline away (move ...) & bee & bëé \\
\hline
\end{tabular}




\begin{tabular}{|c|c|c|}
\hline awl & ‡'orop/s & fòròs [D]; (łóm) $\|$ nàös [N] \\
\hline axe & l'oos (?) & !őós \\
\hline \multicolumn{3}{|l|}{ B } \\
\hline baboon & $\begin{array}{l}\text { łnaatap, łneedap, } \\
\text { Inaidap, Ineerap, }\end{array}$ & $\begin{array}{l}\text { Inëèräb, Inöòräb, } \\
\text { łhàt's àöb; "lärúb [D] }\end{array}$ \\
\hline baby & łxam looda-i & $\begin{array}{l}\text { |gőárò-i; |gőórò-i [N]; } \\
\text { därórö-i }\end{array}$ \\
\hline back & **\|'âp; \|x'âp [K] & \|äáb \\
\hline \multirow[t]{2}{*}{ bad } & fxabusa $[\mathrm{K}]$ & fkhàwùsä (= weak), tsüù \\
\hline & $\|$ 'ausa $[\mathrm{K}]$ & \|áù (= useless) \\
\hline badger & daniskuna'tû, ||'haup & |härèsëb [D]; |härébäb [N] \\
\hline bag & $\|$ 'hoop & \|höób/s \\
\hline $\begin{array}{l}\text { bag (carried over } \\
\text { shoulder) }\end{array}$ & g\|arus & \|gärùs \\
\hline \multirow[t]{2}{*}{ bald head } & l'oodanap, !naap & $\begin{array}{l}\text { lóòdänáb, !naadanab, } \\
\text { łgàädänáb, łgàäs }\end{array}$ \\
\hline & l'oba!'aap & !ùwüdänáb \\
\hline baptise & l'âl'â & \|àä\|näà \\
\hline barn owl & !'hams & sëréb, |hửúłgùïb \\
\hline bark $v$. & \|'huu & \|hùü \\
\hline basket & I'harup & Ihärùs \\
\hline bead & karap & kärás \\
\hline beads & |x'aiku & $?$ \\
\hline \multirow[t]{2}{*}{ beard } & kx'ail'hom/ail'hom(-ku) & |höò-äḿs > |höḿs \\
\hline & Inomku & |nöms, |häús \\
\hline beat (w. stick) & $* * \neq$ nau & łna̋ú \\
\hline beast ("gedierte") & $\|$ gaaxuu $^{26}$ & |gürúb \\
\hline beautiful & îsa & î̀sä \\
\hline because of & f'ama $[\mathrm{K}]$ & !aroma; łàmà (about) \\
\hline bee & Inanip, !'habup & !häwúb \\
\hline $\begin{array}{l}\text { beetle (small black w. } \\
\text { white underside, } \\
\text { eats skins) }\end{array}$ & !û!ûp & $?$ \\
\hline before, in front & *ai!'â; kx'ai!'â [K] & äílàà̀ \\
\hline beg & fona & $\begin{array}{l}\text { łgònà (wait patiently like dog), } \\
\text { |khówè }\end{array}$ \\
\hline beggar & łonakx'aop & |khówè-àöb \\
\hline behind & khaop kx'ai; khao!a [K] & khäó!gằ, khäós áì \\
\hline belch & g!ai & !gäì \\
\hline believe & fom & łgòmm \\
\hline bellow & !oro, g!oro & !görò (of: bull); !göó \\
\hline bend & $\mathrm{g} \|$ obag $\|$ oba & !höá!hòä, gämàgàmä \\
\hline
\end{tabular}

\footnotetext{
${ }^{26}$ Supplied by Gert Maerman.
} 
(8) Hee lx'urip ir na $\quad$ \|loba g\|oba.

!hoa !hoa.

this iron- $\varnothing$ I PR bent $\sim$ CAUS

'I am bending this iron'

bend (limb); fold
bend over
bent (not sharply)
bent - sharply (of: short
object)
berry

beside, next to

next to me

beverage

beware of

bewitch

bicycle

big

birthmark

bite

bitter

black

black thorn

bladder

blanket

blind - be

blow (w. mouth)

blow (nose)

blow (of: wind)

blue

blue wildebeest

blunt

body

boil $v . i$

boil $n$.

bone

bore, nauseate

!'hon [K]
g\|lobag\|loba
!am!'aa
g\|lobasa
!'hoba
głararap
|xaroro
ti |xaroro
kx'aaxuup
!ôibasen
f'anabasen
g!ai
|x'urihaas/p
kai
ł'habas
baa [K]
kx'au
łnuu
!noes
*\|x'urup
!xons
|'hamkx'ai

!nasi, !nai

xuni

!om

g!oa, !noa

‡xôap

f'ubu, f'unu

Ixaap, arep

$|\hat{u}, * * g| \hat{u}$

*tshuip

¥xoop, |xoop

kx'uixa
Nee luriba ta ge ra

this iron-OBL I IND PR bent CAUS

!höǹ

!höá!hòà, gämàgàmä

!gàm!âa 4

\|göwà (= bow-legged) 3

!höńsä

0

抽rás (pip, seed) 1

xőólkháà, xőórì 0

tî xóòlkháà

áàxùüb 4

!ừíbäsèn, !ựísèn 3

łànbàsèn; łànàbăsùn $[\neq \mathrm{Aa}]^{27}$

!gäì

lùr"̈ háàb 4

käí 4

łnàős 0

năá

àü 4

łnüù 4

!nöés 4

\|khùrùs 2

!khòǹs/!khèǹs (= patchwork bl.) 4 łnäms (= kaross)

fgìì 0

|hamai, samai (= operate on s.o.

for cataract)

!nàí 2

xúnì 4

!góm 4

thöà 0

gäób 0

łùwù; łùù $[\mathrm{D}]$

|khäáb 4

gừù 4

tsùîs 4

łkhòőb 4

ùixä káì 3

\footnotetext{
${ }^{27}$ The apparent nonelision of the final vowel $-a$ in Xri ł'anabasen and ¥Aakhoe and Haillom łànàbäsùn, to the exclusion of mainstream Khoekhoe, is some striking bit of evidence for the etymological link of these geographically most removed lects. Cf. also Haacke (2014: 136) for ‡Aakhoe łànàbäsùn.
} 


\begin{tabular}{|c|c|c|}
\hline born - be & !nae & !näé \\
\hline borrow & *|'hubi; |xubi ${ }^{28}$ & |khűwí \\
\hline bother & $* \|$ 'ora & \|nora \\
\hline *n|'huuxa & |hüú (kái) & \\
\hline bowl & !'ores & !örés \\
\hline boy & kx'aoloodap, aoloodap & $\begin{array}{l}\text { àòre̋ |góàròb//góòròb } \\
\text { a̋áxäròb, därób }\end{array}$ \\
\hline brain & łxôp & łkhừùb/s \\
\hline bran & f'amaroku & lhőób \\
\hline bread & baredas, berep, perep & pẻréb \\
\hline break & khôa & khōá $\quad v . t$; khōá v.i \\
\hline breast & sammi & säḿs/mi \\
\hline breathe & l'om & lòm \\
\hline breathe strongly (sniff) & *|'ubi & |hüwì \\
\hline bring forth young & *ôa & òä (of: anim.) \\
\hline broad & f'habasa & fhäwá \\
\hline brother & !âmp, !âp & !găááb, !găásäb \\
\hline brother-in-law & l'uip & lùìb \\
\hline brown & !oa, g!oa & fgàmà \\
\hline brown hyena & glaip & łnüúbéłhìiräs \\
\hline bubble out (of: spring) & g!amał'ui & fùwï \\
\hline buchu & sâp & săááb \\
\hline bud (of: tree) & $\|$ 'hai & $\begin{array}{l}\text { !ùmì; göá (of: esp. acacia) } \\
\text { \|häì (= germinate) }\end{array}$ \\
\hline buffalo & $\neq$ ұaop & |gáòb \\
\hline bull & $\mathrm{g} \|$ oop & \|göòb \\
\hline bull-calf & kx'aogomadap & tsặúb, \|göòtsà̀üb, Inōàb \\
\hline bullet & |x'urip & !a̋wúlùrìs, \|hääs \\
\hline bundle $v$. & !ae-am & !gäé-ám, !gäélkháà \\
\hline burn & !'am & !ämó (= light (candle, torch)) \\
\hline burn (of: fire) $v . i$ & khau, khabu & khäú v.i \\
\hline (of: fuel) & f'hubi & łhüwí $v \cdot i$ \\
\hline burn, bec. scalded & dâu & däú \\
\hline bury & $\|$ xoo & \|khóò \\
\hline Bushman & |Xâusaa-i, Saa-i & Sàà-i \\
\hline bustard? & har\|aallaa & $\begin{array}{l}\text { xàrtsiil|gáàl|gáàs/gäàräs (= black } \\
\text { korhaan) }\end{array}$ \\
\hline butcher bird & fâkx'anis ("hang+bird") & $?$ \\
\hline butter & $\begin{array}{l}\text { gôan di } \| \text { nuip ("cow+ } \\
\text { fat") }\end{array}$ & !khàö(\|nùì)b \\
\hline buttocks & $\begin{array}{l}\text { f'areku, } \\
\text { !ubiku, *g!ubuku }\end{array}$ & $\begin{array}{l}\text { färédi } \\
\text { !gùwíra (vulg.) }\end{array}$ \\
\hline by (ag.), about & xa & xà \\
\hline from (source) & xa & xà \\
\hline
\end{tabular}

${ }^{28}$ Supplied by Jan Kok, Campbell. 


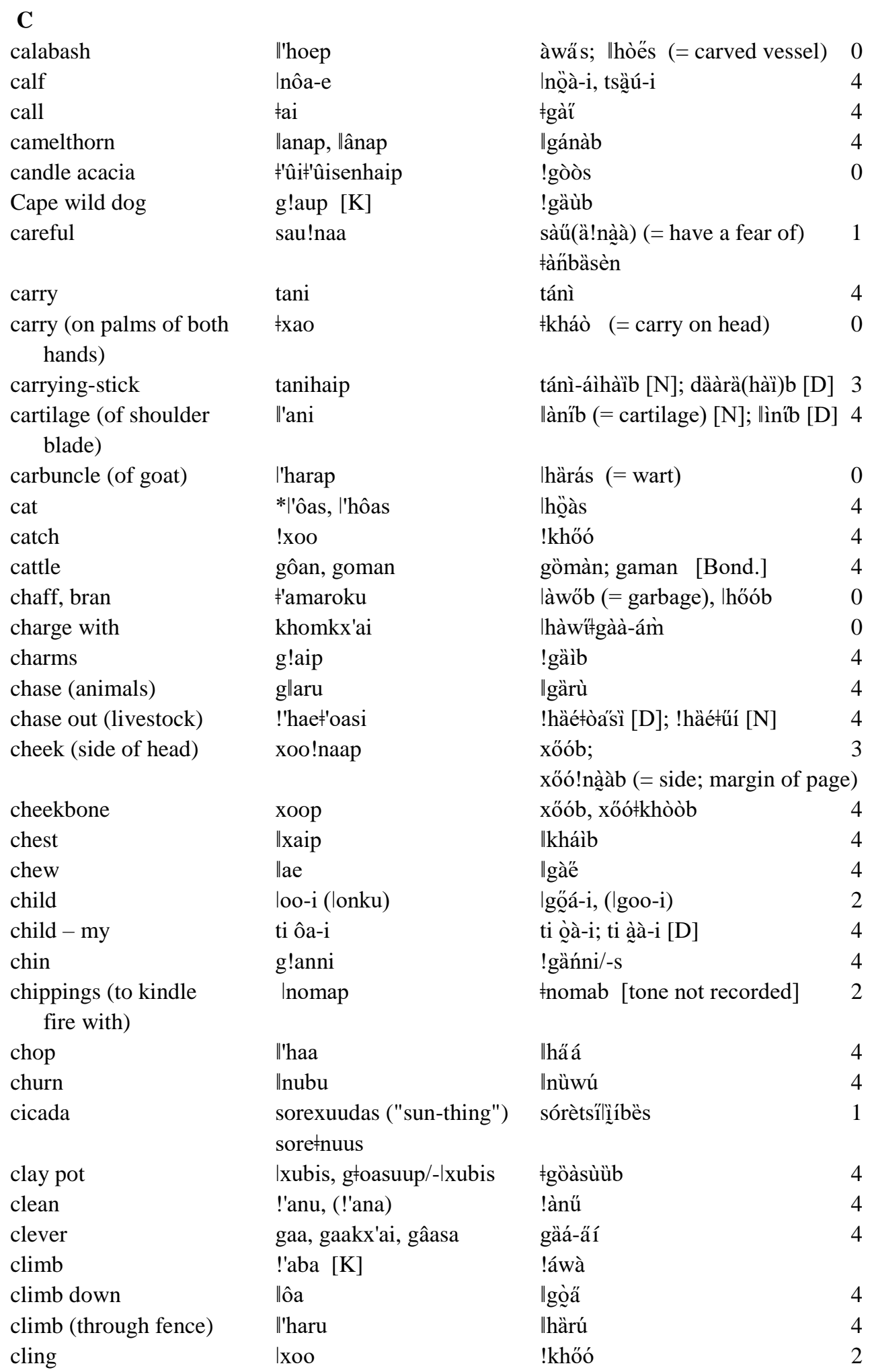




\begin{tabular}{|c|c|c|}
\hline close & łanam & łgâńám \\
\hline cloth & laa-i & läá-i (< Afr. lap) \\
\hline clothes & !xanku & sáràn \\
\hline cloud & Inanus; |'hommi & $\begin{array}{l}\text { Inànüs; !àüs [D]; |hömmi } \\
\text { (= heaven) }\end{array}$ \\
\hline coarse, rough & |xoara & |khóà; |khórà \\
\hline $\operatorname{coccyx}$ & Inanip & Inánàb, Inánìb \\
\hline cold $a$. & !xai, *!hai & !khài" \\
\hline cold (med.) $n$. & !xail'oop; |x'ôas [K] & lóàs \\
\hline come & haa & häà \\
\hline come back, return & !'hoba & !höwà \\
\hline come across & |'hao & |hàö \\
\hline comfort (child) & !noo!noo & !nőó!nòö \\
\hline complain & sii!nuri & siï !nùrï \\
\hline $\begin{array}{l}\text { congratulate (by pop- } \\
\text { ping finger) }\end{array}$ & !'awu & $?$ \\
\hline contemporary - my & ti khama gaidas & ti \|hàäb \\
\hline convene & l'hao(gu) & |hàö, |hüù̀ \\
\hline converted -be & daba!xunigu & $\begin{array}{l}\text { !khùnï, !höwàsèn } \\
\text { (däwá!khùnî= turn (s.) back } \\
\text { to point of departure) }\end{array}$ \\
\hline cook & sâi, sâsî & så̀í \\
\hline cooking shelter & !nuup & \|gànìs \\
\hline $\operatorname{cool} v . t$ & !xai!xai & !khäí!khàì \\
\hline corn & I'hû(n)!'horop & !höròb \\
\hline corner (of house) & !nanip/!'anip & $\begin{array}{l}\text { !näníb/!ánìb (= other/far side); } \\
\text { "hộás, óm̀s di łgüís }\end{array}$ \\
\hline correct & ‡'hanu & fhànü \\
\hline cough & \|'ui & \|úì \\
\hline count & !ôa & !gőá \\
\hline cover (w. cloth) & $\mathrm{g}$ !uu & !güú \\
\hline cow & gâs & gömàs; gämàs [Bond.] \\
\hline cowardly & $\begin{array}{l}\text { łxabusa łaop î (w. } \\
\text { weak heart) }\end{array}$ & !áò!nàà̀ \\
\hline crack, burst open & !'hui & !hüí \\
\hline crack $v . i$ (of: e.g. cup) & $\neq x a b e$ & fkhàwè \\
\hline crack (whip) & !oa & !gòä \\
\hline crank & $\|$ xami & \|khàmï \\
\hline crawl (like baby) & f'hana & łhänà \\
\hline (like child) & !nuru & $\begin{array}{l}\text { !nuru }(=\text { move on buttocks }) \\
\text { [no tone] }\end{array}$ \\
\hline cream & $\begin{array}{l}\text { !x'abup, !x'abop } \\
\text { !'abup, !'abop }{ }^{29}\end{array}$ & !àòpëb < !awob (Kroenlein 1889)2 \\
\hline cricket & |'hâil'harip & łgìrïłgìrís, \|gàm"łkhùríb \\
\hline
\end{tabular}

\footnotetext{
${ }^{29}$ Supplied by Gert Maerman.
} 


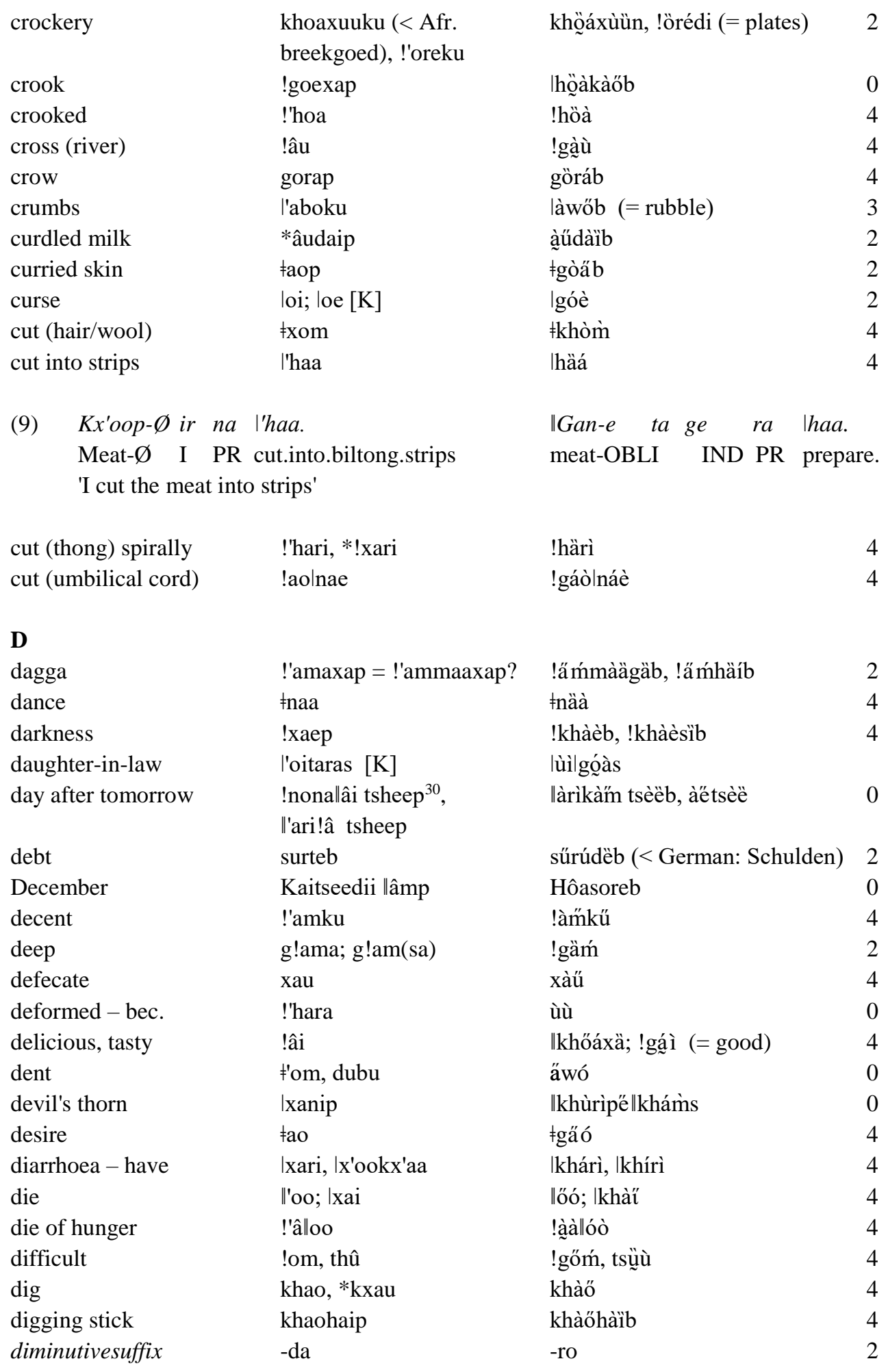

${ }^{30}$ Supplied by Gert Maerman. 


\begin{tabular}{|c|c|c|c|}
\hline $\begin{array}{l}\text { dirty } \\
\text { disgrace }\end{array}$ & $\begin{array}{l}\text { l'urisa ; |x'uril|x'urisa } \\
\text { taop }[\mathrm{K}]\end{array}$ & $\begin{array}{l}\text { lùrîsa̋//ùrîxä; |ürílùrìsä } \\
\text { táòsïb, táòłnàòs }\end{array}$ & 4 \\
\hline dish & !'ores & !örés & 4 \\
\hline dishonest & g!uisa, g!uixa & Ihōàkàő, ảmäò!nå̀à & 0 \\
\hline disjointed & $\|$ xuri & $\|$ khùrì $[\mathrm{D}] ;$ !òë $[\mathrm{N}]$ & 4 \\
\hline disobedient & kooxa & \|nå̃úò\|nà̀à & 0 \\
\hline divide & gloara, glora & 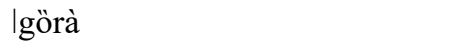 & 4 \\
\hline doctor & g!aixap [X] & $\begin{array}{l}\text { !gäì(dî́)-àöb; !gäiöb } \\
\text { [D] (= shaman) } \\
\text { sőólòàdî́-àöb/s }\end{array}$ & 3 \\
\hline done, cooked & I'ansasa & \|äńsä & 3 \\
\hline door & $\| x o b a s$ & däòs; (cf. \|khòwä-ám v. open) & 0 \\
\hline Douglas; Vaalriver & Głauxunup & - & \\
\hline draw in (head) & \|ansen, łaełâ & |hüríłgàà & 0 \\
\hline draw (tail between legs) & łnaba & łnäwá ? (= arrange skirt); \|näwé & $? 0$ \\
\hline draw water & xuri $[\mathrm{K}]$ & xùri" & \\
\hline dream $n$. & $\|$ 'habop & \|hàwős & 4 \\
\hline $\begin{array}{l}\text { dress } v . \\
\quad \text { !xansen; *ana }[\mathrm{K}]\end{array}$ & $\begin{array}{l}\text { **głaełâ; łaełaa } \\
\text { àná }\end{array}$ & łgàèłgàà & 4 \\
\hline $\begin{array}{l}\text { driedoring Rhigozum } \\
\text { trichotomum }\end{array}$ & $\|$ 'hauka $[\mathrm{K}]$ & \|häúb & \\
\hline drink $v$ & kx'aa & áà & 4 \\
\hline \multirow{2}{*}{$\begin{array}{l}\text { (10) } \quad \text { 'Hunip- } \varnothing \\
\text { Shepherd's.tree- } \varnothing \\
\text { 'I drink witgat coffee' }\end{array}$} & $\begin{array}{llll}\text { ir } & \text { ke } & n a & \text { kx'aa. } \\
\text { I } & \text { IND PR } & \text { drink }\end{array}$ & $\begin{array}{lll}\text { IHunib-a ta } & \text { ge ra } \\
\text { Sheph.'s.tree-OBL I IND PR }\end{array}$ & $\begin{array}{l}a a . \\
\text { drink }\end{array}$ \\
\hline & & & \\
\hline drink $n$. & $\begin{array}{l}\text { kx'aap, łnaa-am, } \\
\text { !'hai-am }\end{array}$ & $\begin{array}{l}\text { áàb, } \\
\text { !häì (=v. bottle-feed) }\end{array}$ & 4 \\
\hline drink, suckle & dai, bii & däì & 4 \\
\hline drip $v$ & l'aml'am & łnåăá & 0 \\
\hline drive (animals) & $\mathrm{g} \|$ aru, diikhao & \|gärù, dííkháò & 4 \\
\hline drought & l'oop & |khùrüb & 0 \\
\hline drown & kx'aall'oo & ààlőó & 4 \\
\hline drowsy - bec. & f'omi $(? ?)^{31}$ & fòm hî̀ & 2 \\
\hline drunkard & |'horosmap & |hòrős(è)mà̀àb & 3 \\
\hline \multirow[t]{2}{*}{ dryl'oo, l'uu } & lóò $(=$ cease to produce milk & & 4 \\
\hline & |'ûkhâisi, |'uu//'oo (ha) & łnäà (= bec. dry) & \\
\hline dry $v . t$ & l'aa làä?, = squeeze, press) & & 4 \\
\hline duiker & glaro-e & dọás [N]; Inäùb [D] & 0 \\
\hline \multirow[t]{2}{*}{ dull, dense } & gâ & gạaà(rë) & 4 \\
\hline & g!ookhoe, g!ooke & !khựúkë [D] & \\
\hline dung (wet) & f'haup & fhäùb & 4 \\
\hline dung-beetle & xau!norap & xàügàrìs, \|gàmàbëb, kùmïs & 1 \\
\hline
\end{tabular}

31 "(??)" questions correctness of information. 


\begin{tabular}{|c|c|c|c|}
\hline \multicolumn{2}{|c|}{$\begin{array}{l}\text { dust } \\
\text { dust (fine powdery soil) }\end{array}$} & $\begin{array}{l}\text { tsharap, tharap } \\
\text { f'oap }\end{array}$ & $\begin{array}{l}\text { tsäráb } \\
? \quad \text { ( fgöàb = clay })\end{array}$ \\
\hline \multicolumn{4}{|l|}{$\mathbf{E}$} \\
\hline \multicolumn{2}{|l|}{ eat } & f'û & fù̀ü \\
\hline \multicolumn{2}{|c|}{ eagle owl } & !'hûros, !'hû!'hûs & $\begin{array}{l}\text { !hựúròs (= pearl spotted } \\
\text { owlet) }\end{array}$ \\
\hline \multicolumn{2}{|l|}{ ear } & \|nâump & fgàëb （\|na्aú = hear $)$ \\
\hline \multicolumn{2}{|c|}{ early } & $\|$ oaba, $\|$ oaka & \|góàgä \\
\hline \multicolumn{2}{|l|}{ east } & sorel'uis & sórès \|häilkháàb, \|góà|gäḿs \\
\hline \multicolumn{2}{|l|}{ easy } & sui(sa) & $\begin{array}{l}\text { suisui }[D] \\
\text { (of low density > easy) }\end{array}$ \\
\hline \multicolumn{2}{|l|}{ edge } & g\|arap (of e.g. book) & !nämmi \\
\hline \multicolumn{2}{|l|}{ egg } & Inarap, !'ubup & !ùwüs \\
\hline \multicolumn{2}{|c|}{ eggshell } & !'uwub khôa & !ùwüłkhòròs \\
\hline \multicolumn{2}{|c|}{ eight } & $\| x a i s i$ & $\begin{array}{l}\text { \|khäísä; ॥khäésa̋ } \\
\text { [Bond.] }\end{array}$ \\
\hline \multicolumn{2}{|c|}{ elbow } & !'unip & !ùníb \\
\hline \multicolumn{2}{|c|}{ elephant } & $\neq$ ‡oap & łkhòàb \\
\hline \multicolumn{2}{|c|}{ elephant shrew } & $* \| \mathrm{xaup} / \mathrm{s}$ & bäús; !khàü(łgüí)b \\
\hline \multicolumn{2}{|c|}{ eleven } & *yisi luil'a & dî́sí |güílàà \\
\hline \multicolumn{2}{|c|}{ elope } & duni & düní (= abscond) \\
\hline \multicolumn{2}{|c|}{ ember (glowing) } & |x'ais, łnummi & łnöm̀s (= coal), dünúb \\
\hline \multicolumn{2}{|c|}{ empty bowels } & $\| \mathrm{au}$ & xàü \\
\hline \multirow{2}{*}{\multicolumn{2}{|c|}{ end }} & !aap & lùnïs \\
\hline & & l'ammi & làms \\
\hline \multicolumn{2}{|c|}{ energetic } & $\|$ ari & sì̀sènxä, làēxä \\
\hline \multicolumn{2}{|c|}{ enter } & fâ & fgà̀à \\
\hline \multicolumn{2}{|r|}{$\begin{array}{l}\text { Tir ke kx'ommi } \\
\text { I IND house } \\
\text { 'I am entering theho }\end{array}$} & $\begin{array}{ll}\text { !nâ } & \neq \hat{a} . \\
\text { in } & \text { enter } \\
\text { use' } & \end{array}$ & 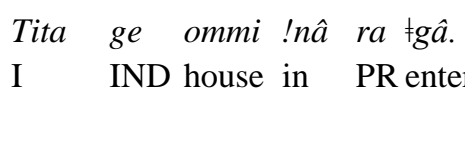 \\
\hline \multicolumn{2}{|c|}{ European } & $\begin{array}{l}\text { |'Hôp; |'Hû(m)p } \mathrm{p}^{32} \\
\text { |'Hûnkhoep/s }\end{array}$ & $\begin{array}{l}\text { IHựúb } \\
\text { (|höńkhòèb = master, boss) }\end{array}$ \\
\hline \multicolumn{2}{|c|}{ exhausted - bec. } & $\neq x a b u$ & łkhàwù, tsàü \\
\hline \multicolumn{2}{|c|}{ exit } & |x'oa(sii) & fòä \\
\hline \multicolumn{2}{|c|}{ explain } & !'hoaba!'aa & (!hoa!aaba), mî̀!’àä \\
\hline \multicolumn{2}{|c|}{ explain (genealogy) } & IIxobesa & süríłgàè (= correlate ancestries) \\
\hline \multicolumn{2}{|c|}{ eye } & mûmp, mûp & müús \\
\hline eyeb & ow & glâuku; Inamp [K] & $\begin{array}{l}\text { |gạù̀; lámmèb; lámmìb [N] } \\
\text { (= cilium) }\end{array}$ \\
\hline eyela & shes & mûl'ûku & müúlàmmmëgu \\
\hline
\end{tabular}

\footnotetext{
${ }^{32}$ Obtained in Griekwastad
} 


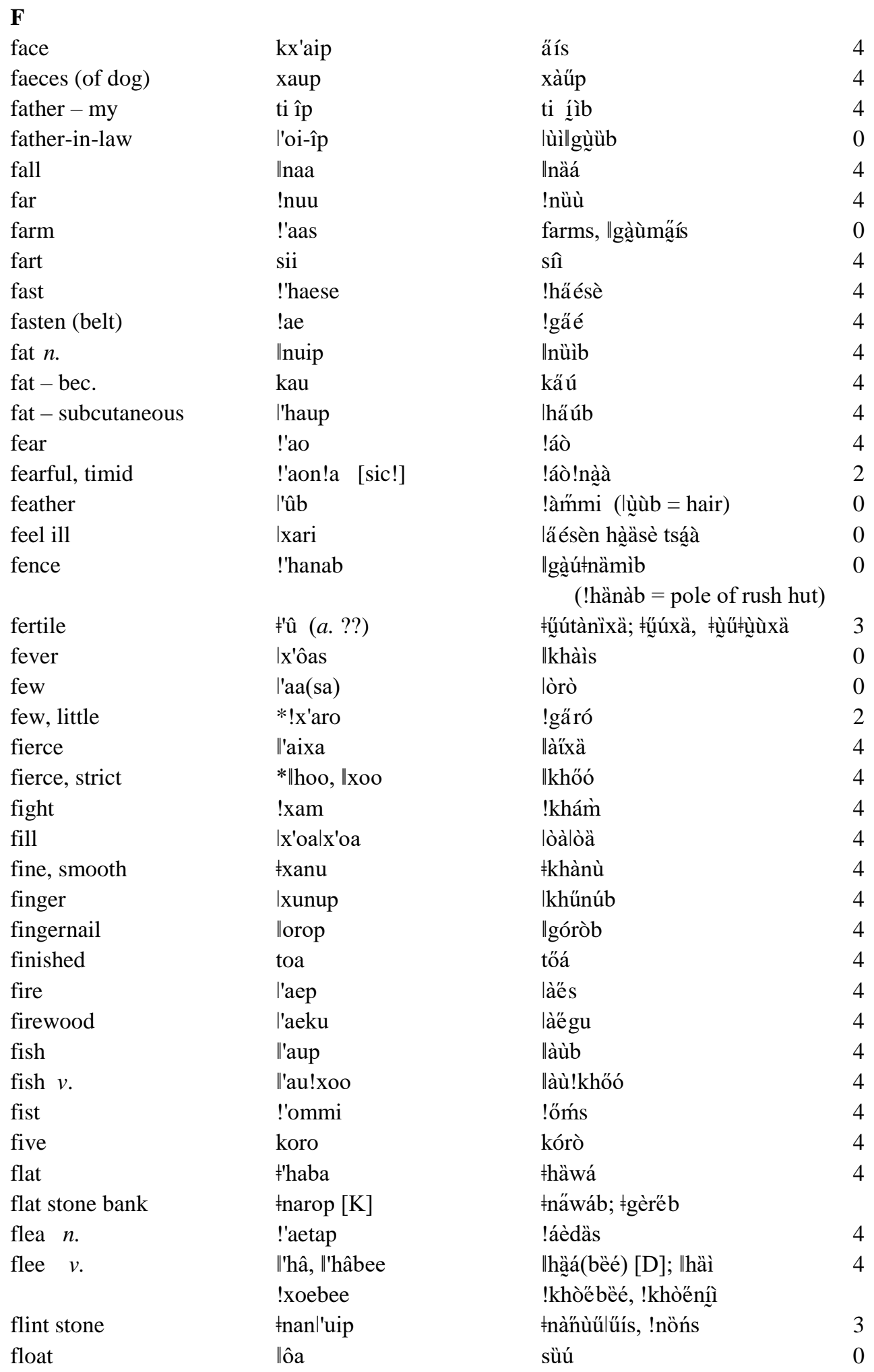




\begin{tabular}{|c|c|c|}
\hline flow & g!ama & dậú \\
\hline flute & f'aap & fáàb/s (= reedflute) \\
\hline fly $n$. & $\begin{array}{l}\text { lanap, lainap }{ }^{33} \text {; lanip } \\
\text { l'amip, Inanip }\end{array}$ & |gìinàs, |gèènàs \\
\hline fly $v$. (of: bird) & doe & döè, \|khànà \\
\hline floor & kx'ommi !'huup & fáiłgàwàb \\
\hline foal & łxam haada-e & fél-i (< Afr. vul) \\
\hline fog & taurap & $\begin{array}{l}\text { taus ?, Ihàn”s, tsàn̂tö(r)ós; } \\
\text { huris (coastal/winter fog) }\end{array}$ \\
\hline fold (up) $v$. & !'hon & !höǹ; !khőń \\
\hline follow & sao(!aa); !ûl'ae\|'ae & säó \\
\hline foot & f'aip; ł'aip/łnaip [K] & fáib \\
\hline underside of my foot & ti ‡'ai!naka & ti $\neq$ ais (di) !naakab \\
\hline ford $v$ & xanu & xànü \\
\hline ford, drift $n$. & xanup & łhîis; Inüú(!gùù)!gà̀ú-áms \\
\hline ford (near Douglas) & g!auxanup $[\mathrm{K}]$ & - \\
\hline fore-arm & ‡'hâp & łhà̀äb \\
\hline forehead & !'uub/s, !'uuš & !üús \\
\hline forget & l'uru & lùrù \\
\hline forgive & l'uruba & |ùrùbä, |ùuübà \\
\hline fountain & |x'aus, |'audas & |àüs, làüròs \\
\hline four & haka & hàkà \\
\hline fowl & *anis $[\mathrm{X}]$; kukurub $[\mathrm{K}]$ & $\begin{array}{l}\text { ànïs; hüńgùrïb (< Herero) } \\
\text { kukuru }\end{array}$ \\
\hline freeze to death & !xail'oo & !khài" I óò \\
\hline friend & \|'omakhoe-i & sòrë-i, hòrë-i, güríb, \\
\hline friendship & $\|$ 'omasip & khöèhőrésägüb, khöèxäsïb \\
\hline fright - get a & !'huri & !hürí \\
\hline from & $\mathrm{xu}$ & $\mathrm{xu}[\mathrm{xùü}]$ \\
\hline frost, May & !x'abap, !'abap & !khòàb (!áwàb = spring) \\
\hline frown & Inuni-ai & lìníǹáì \\
\hline full & |x'oasa, |'oasa & lòàsa̋ \\
\hline fungus (yellow powdery) & l'hobos & $\begin{array}{l}\text { !nàüb } \\
\text { (lhőwó = v.paint face w. } \\
\text { ointment made from !nàüb) }\end{array}$ \\
\hline future $t$. & ni & nî \\
\hline \multicolumn{3}{|l|}{$\mathbf{G}$} \\
\hline gallop & !'are & !órè \\
\hline gargle & $\mathrm{g} \|$ obo & \|göwópéǹám!nnàà, \|göwópe̋ \\
\hline garden & !'hanap & !hànäb \\
\hline garment & tanip, !xanip/!xanku & ànáxùù-i \\
\hline gather & |'hami, xami & $\begin{array}{l}\text { Ihämí; xämí (= gather \& roll up } \\
\text { blankets) }\end{array}$ \\
\hline
\end{tabular}

${ }^{33}$ Beach (1938: 194): Korana lenap. 


\begin{tabular}{|c|c|c|}
\hline & |'haol'hao & |häólhàö \\
\hline generation & !'haos & süríb (!häòs = family) \\
\hline genet & tool'hôas & !nörèb \\
\hline germinate, grow $v \cdot i$ & \|'hai & \|häì, !iī \\
\hline get erection & kx'ôa & |khàmä \\
\hline \multirow[t]{3}{*}{ girl } & loos & |gõás \\
\hline & laaloodas, taareloodas & |gọáá(rò)s \\
\hline & 'oaxais & őáxáès \\
\hline - young & I'habasas & |gợáròs \\
\hline give & $\mathrm{au}$ & mäà (äú = let share in) \\
\hline \multirow[t]{2}{*}{ give birth } & $\|$ 'ora & \|òrä (of: esp. human) \\
\hline & ôa & òä (of: anim.) \\
\hline glans (of penis) & xâp di bi!'âp [K] & tsöràb \\
\hline \multirow[t]{2}{*}{ glue, affix (?) } & f'abe & fäwé, łàè \\
\hline & & (= sit glued to, adhere to) \\
\hline \multirow[t]{2}{*}{ glutton } & $\|$ 'harip & òő-àö-i \\
\hline & & (cf. \|harisa arch. gluttonous) \\
\hline go out & f'oa & fòä \\
\hline \multirow[t]{2}{*}{ God } & Tshuull'aop, Tshiill'aop & Élób, !Khùùb, Äwób; \\
\hline & $\begin{array}{l}\text { Tshiill'oa, Siilloap, Suu- } \\
\text { "oap, Abop, Elo, !Xuup }\end{array}$ & Tsuillgoab arch. \\
\hline gone (absent) & kaa, |xai & káà, |khàï \\
\hline good & *!'âisa & !gạ́ì \\
\hline gossip & l'hoe & |höè \\
\hline grab & !xoo, *zubu & !khőó, tsüwú \\
\hline grain bag & \|'hoop & \|höób/s \\
\hline grandchildren (my) & ti loon di oan $[\mathrm{K}]$ & ti òàn di lgóàn \\
\hline grandfather & \|ûp; \|naup [K] & \|näò(sä)b, àüta̋b \\
\hline grass & lâp, lamp & |gà̃äb \\
\hline grave $n$. & l'hobap & |höwás \\
\hline graze & !'û & !ùü \\
\hline green & !x'am, !'am & !a̋ḿ \\
\hline green, unripe & kx'oara & òrà \\
\hline \multirow[t]{2}{*}{ greet } & nebe, nabe(te) & täwédë; näwédë [D] \\
\hline & & (na̋wé = beckon) \\
\hline \multirow[t]{2}{*}{ grey } & l'hai & 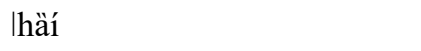 \\
\hline & thaothao & tsaotsao (= ashen) \\
\hline grey $v$. (of: hair) & !noa & !nòä \\
\hline Griekwa language & Xri!'hoap & \\
\hline Griekwa people & Xirikwana, Xurukwana & \\
\hline
\end{tabular}

$\begin{array}{lc}\text { Tita } & k e \\ \text { I } & \text { IND } \\ \text { 'I am a } & \text { Griekwa' }\end{array}$
Xurukwa- $\varnothing$.
Griekwa- $\varnothing$
'I am a Griekwa'

Griekwastad

Kai!'aas, !Orał'hôap 


\begin{tabular}{|c|c|c|}
\hline grind (cereal) & xun & xőń, xëń \\
\hline groan & $\mathrm{g} ! \mathrm{ae}$ & !gäè \\
\hline grope & *thâthâ & $\begin{array}{l}\text { tsa̋nánä` tsäánä; } \\
\text { |gẩ wó, Inâálnáà, tsömmè }\end{array}$ \\
\hline ground-squirrel & saop & |gäéłnàäb [D] \\
\hline grow (of: anim.s, plants) & \|'ui & "üí (= thrive, flourish) \\
\hline good & !âi & !gá্ì \\
\hline guilty & l'habixa & |hàwi̋xä \\
\hline guinea fowl & tookx'anis (?) & |khénäs $\quad($ tòö $=$ mottled $)$ \\
\hline gullet & |x'abadommi & läwádòmmi \\
\hline gully & !'aap & łnämmi; $($ !áàb = river $)$ \\
\hline gum (of tree) & hairap & häíräb \\
\hline gum (of jaws) & arika, \|ûkx'oop & àríb \\
\hline \multicolumn{3}{|l|}{$\mathbf{H}$} \\
\hline hair & $\begin{array}{l}\text { l'ump, l'ômp, l'ûku } \\
\text { |xomku }\end{array}$ & lừùb \\
\hline hamerkop & !'hams & $?$ \\
\hline hammer & l'urip & hamers $($ ùríb $=$ iron $)$ \\
\hline hand & !'ummi, !'ommi & !őmmi \\
\hline hang, suspend & łaami < łaamai & łgàämăáí \\
\hline hang (to execute) & fâ & łgàä \\
\hline hard - bec. & karo & kàrő \\
\hline hardworking & !ari & !gàrï (= indefatigable) \\
\hline hare & !'ôas; *|'ôas & !ờàs \\
\hline hat & $\|$ 'haep/s & |gáwàs \\
\hline \multirow[t]{2}{*}{ hawk } & |x'aup; & läúb \\
\hline & kuku!xookx'aop ("fowl-c & cher") $[\mathrm{K}]$ \\
\hline \multirow[t]{2}{*}{ head } & danap & dänáb \\
\hline & $\begin{array}{l}\text { bii-/baa-/bee!'amp; } \\
\text { bii!'âkwa [K] }\end{array}$ & \\
\hline head - back of & !norop & !nòrős \\
\hline head cloth & !xaip & !khäíb \\
\hline heap of stones & !oro & !närób/s \\
\hline hear & \|nâu & \|näú \\
\hline heart & łaop & łgäób \\
\hline heartbroken & łaotshû & łgäótsừù \\
\hline heat - be on & sâ [K] & sőḿ (of: bitch) \\
\hline heaven & |'hommi & |hömmi \\
\hline heavy & !om & !gőḿ \\
\hline hedgehog & łxam !noap $(=$ young $\sim)$ & |gàmürős (!nòäp = porcupine) \\
\hline heifer & $\begin{array}{l}\operatorname{lnoa}(\mathrm{da}) \mathrm{s} \\
\text { taralnoas }[\mathrm{K}]\end{array}$ & $\begin{array}{l}\text { Inöà(rò)s, tsäús, } \\
\text { täránùùu gòmäs/tsäús }\end{array}$ \\
\hline height, steep cliff & 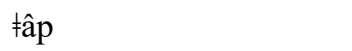 & łgà̃äb [D]; \#höáb [N] \\
\hline help & hui & hüí \\
\hline herd (cattle) v.t & !'ûi, !'ôasi & !ụí, !oِásì \\
\hline
\end{tabular}




\begin{tabular}{|c|c|c|}
\hline herbivorous animal & xamarep & xảmárì-i [N]; xämánī-i [D] \\
\hline heron & \|'au-anip (= "fish-bird") & rëìr-i (< Afr. reier), |gùr"' khòèsèb \\
\hline hiccup & $\|$ 'ubi & \|ùwï [D]; \|nùwï \\
\hline hide & $\| x a r u$, gaugaubee & \|khàrü (= put away for later); sấu \\
\hline hide o.s. & gau, gaugau & gäù \\
\hline high & f'amka & fám!nà̀à (= on top of); Igàwï(sè) \\
\hline & !urisa & !gùrísè (= at high altitude) \\
\hline hill & farerep & !nàüb, !nőḿmi \\
\hline hillock & khuup & khüùbës (= bulge); !nà̀üròs \\
\hline hinder & \|'ore & fhänì; (\|órè = abuse, maltreat) \\
\hline hip & f'hobep; & $\begin{array}{l}\text { łhöwèp [D] / !gòwëb [N] } \\
\qquad \text { (= flank, waist })\end{array}$ \\
\hline & glubup, Inubup & |güwús, Inüwús (= area of hip) \\
\hline & fommi & łnőḿmi (= area of external thigh) \\
\hline hippo & ‡xoas (??) & !khàòs (łkhòàb/s = elephant) \\
\hline hold & !xoomâi & !khòőmäí (= hold upright) \\
\hline hold tightly & !'hau & !khòö|gàrä \\
\hline hole & kx'aas, aap & äás \\
\hline holy & !'anu & !ànü \\
\hline home & hâ!xaep & hàaä!khàìs; hàaä!khàès [N] \\
\hline honey & danis & däníb \\
\hline honeybeer & dani!xarip & däní!khàrìs \\
\hline hoof & $\|$ xoarap & \|khòräs \\
\hline horn & \|namp/\|nâku, *nlâp & \|näààb \\
\hline horse fly & haa-uip & häá|gì̀näb \\
\hline hot & $\operatorname{lam}(? ?=v . i)$. & |gảmásä $a$. \\
\hline hot - bec. (of: fire/sun) & \|xôa & \|khọà \\
\hline house & kx'ommi & óms/-mi \\
\hline how? & hamtii? & màà̀tî" ? [D]; hàmtiì'? [N] \\
\hline hunger & !'âp & !ạàb \\
\hline hurried, be in a hurry & \|'aaxa & !nöésä, \|áàxä (= busy) \\
\hline hurry, haste & !'hae & !hàë!hàèsèn \\
\hline hurt & thûthû & tsüütsừù \\
\hline hyena & |'hûgaop, l'ongaop & (lhöàkàőb = rascal) \\
\hline & ‡'hairap & f'hî̀̀räs, ł'häìràs \\
\hline
\end{tabular}

I

I $\quad$ r, ir; tir

tà; tita [tîítà]; (tir [tîur] [N]) 1

läésèn

(13)

Kaise $r$ l'aesen-a.

Kaise ta ge |aesen hâ.

very I sick [<PERF?]

'I am very ill'

very I IND sick PERF

illness

l'aep (-kwa)

läésènni; läéb

(= raised temperature) 


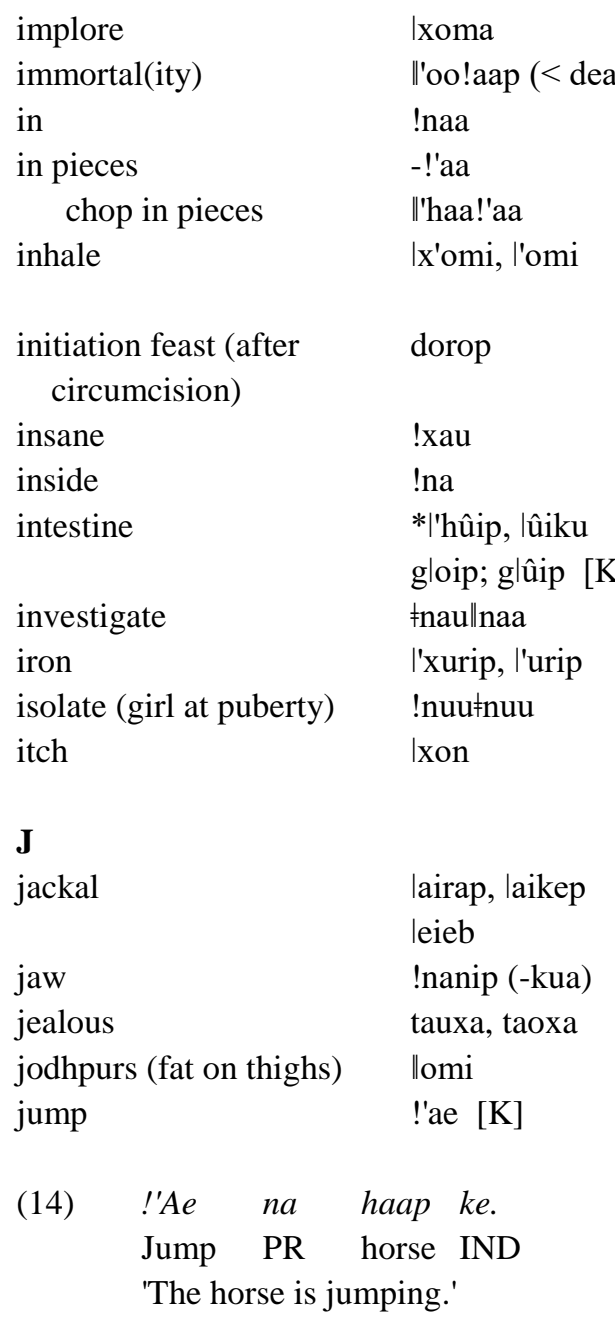

*huri $[\mathrm{K}],[\mathrm{X}]$ |khőmá 4

\|oo \|oa (= can't die) 0

!nà̀à, (!nàà) 4

-!àä 4

\|hàă!àä

lòmłgàà; $\quad 4$

|hőmí (= inhale spasmodically)

?

!khäú; |gärú(ädäná) 4

!nàà, (!nàà) postp.; łgànà $a d v . \quad 2$

|gựíb, |gựígu

4

ọá!nà̀à, ọá!gàó $\quad 0$

lùríb 4

|görà, !guułnûi 0

|khőń [D], |khe̋ń [N] 4

|giîrríb, (|gàîräb) [N]; |gàîre̋b [D]; 4

| giưräb

!nạànïb 2

tàüxä 4

łna̋mími 0

!áè ; örò (= buck)

Oro ra haab ge.

buck PR horse IND

'The horse is bucking.'

ürí

\section{K}

karree (Rhus lancea)

kaross

kierrie, club

key

kick

!'are; !x'are

łnammi

|xarus

l'uris (= iron)

łnaa

!ai

kidney

kidney fat

!naip; !xâp [K]

*âup

!am

gaokx'aop

\|'ôa

\|ôap [X]; \|oap [K]

\|oaku łama maa [K] !àrēs

łnäms

|khärús, !họás

\|khòwä-ámmi

łnäà (kick, dance)

!gáì

!nàts

àün

!gàm

gäó-àöb

\|óà

\|gőás

!höǹlgóà

4

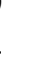

4

4




$\begin{array}{ll}\text { knife } & \text { kôas } \\ \text { knob } & \text { !ubup } \\ \text { knot } v . & \text { !'hû }[\mathrm{K}] \\ \text { know } & \text { ł'an } \\ \text { know not } & \text { l'uu }\end{array}$

$\begin{array}{llll}\text { I'Uu- } & r & k e & a . \\ \text { not.know } & \text { I } & \text { IND } & \text { PS } \\ \text { |'Uu ta- } a \text {. } & \text { [< Nama] }\end{array}$

'I do not know'

Korana (pl.)

kraal

krantz

\section{L}

lamb

lamb (young)

land

late (arrive)

lay a charge

lazy

lead (pers./anim.)

leak

lean - bec.

lean against

leanness

learn

(16)

$\begin{array}{lll}\text { Sisen- } \varnothing & \text { ir } & n a\|x a a \sim\| x a a \sim \text { sen. } \\ \text { work- } \varnothing & \text { I } & \text { PR be.able CAUS REFL }\end{array}$

'I am learning the work'

leave alone

leave (go away)

xuu

doe

Hee !khaip- $\varnothing \quad$ xu $\quad r \quad$ na doe. this place- $\varnothing$ from I PR move 'I am leaving this place'

leave (undisturbed)

॥naa

left hand

-less
!Oran

!'harap

|xaoda-i, |xoada-i

‡xam \|xaoda'e

*!uup

!xaeba (haa)

!nuri

l'obe

!'â

$\neq$ naa

głaba $[\mathrm{X}],[\mathrm{K}]$; $\|$ 'aro [K]

I'arop

\|xaalxaasen g!anasen gòàs

!güwúb (= sphere)

!hüú

łäń

lúù

IUu ta (ge) a.

not.know I IND PS

!Góràn $\quad 4$

!härás 4

łgàăb [D]; \|höáb [N] 4

$\| k h a ̀ o ̀ b / s$

\#khàm \|khàòrò-i 3

!hüúb 2

!öǹkhäó 0

!nùrí!ga्aá 3

lòwe̋s̆a 3

łgáèłgüí 0

łnäá 2

łgäwá 4

!gă्àsèn 2

łgäwá(sï)b 0

\|khààlkhààsèn 4

Sîsens-a ta ge ra

work-OBL I IND PR

$\|k h a a \sim\| k h a a \sim s e n$.

be.able CAUS REFL

xùu 4

döè, döéxùü 4

Nee!khais-a ta ge ra doехии.

this place-OBL I IND PR move.leave

\|näà, \|nààxùü

4

\|àre̋b, \|àrë!ómmi

-ò 
(18)

$\begin{array}{lll}\text { Mari-o } & r & g e \quad h a . \\ \text { money-PRIV } & \text { I } & \text { IND AUX } \\ \text { 'I am pennyless' } & & \end{array}$

leg

level

liar

lick

(19) Thaa $r$ na tami lxa.

Lick I PR tongue with

'I am licking with the tongue'

lid

lie $(n$.)

lie (tell ...)

lie down

lie on back

light $n$.
* |'anaip

ł'hũmi (-ku) [K]

\|aep (-ku) [K]

lae

loe

Ixamp kx'ai

!naap, !nâp, torop $\begin{array}{llll}\text { Mari-o } & \text { ta } & \text { ge } & a . \\ \text { money-PRIV } & \text { I } & \text { IND } & \text { PS }\end{array}$

Inüúb

4

łhäwá 4

łhömì-/łhümì-àöb $\quad 0$

tsäá

4

Tsaa ta ge ra nammi kha. lick I IND PR tongue with

łgänáíb

1

łhümìb, łhömìb

("lgàès $=$ story)

łhümì, łhömì

\|góé

0

$\|$ âa $a i$

!nạáb

4

!Nâb-a ta (ge) ra koo.

light-OBL I (IND) PR look.at

\|khă̌!nạaáb, \|khă̌b di !nã्áb

khäù

4

khäúkhàü

ùükhäí, (łkháò = put on head) 4

náwàb [N]; táwàb [D] 4

INaa-b ge nawaba nawa/tawa. there-he IND lightning strike

!Gam ra nawab ge.

kill PR lightning IND

khämá, khàmî, khèmî

4

like prep.

khama

$\begin{array}{llllll}\text { Hee khoep ge haap khama haa } & \text { Nee khoep ge haap khama ii. } \\ \text { this man } & \text { IND horse like } & \text { PERF this man IND horse like lo }\end{array}$

Hee khoep ge haap khama haa Nee khoep ge haap khama ii.
this man

(23) 'this man is like a horse' 


\begin{tabular}{|c|c|c|}
\hline limestone & !xorop & !khòrőb \\
\hline \multirow[t]{2}{*}{$\operatorname{limp}$} & !'hoara & !hörá (= crippled) \\
\hline & |x'ii & 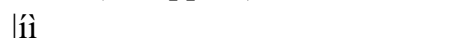 \\
\hline lion & xammi (-ku), *arip & xàmmmi \\
\hline loinskin & \|nabes & \|näwéb \\
\hline lip & kx'ammi & a̋ḿl\|gäúb \\
\hline listen & !â & !gǻà \\
\hline little (a) $a$. & laa & !gäró [N]; |gaa (Rust '69:74) \\
\hline a little water & laa \|amdan & $\ddagger k h a r i \| g a m-i$ \\
\hline little finger & $\begin{array}{l}\text { Ixunudap [K] } \\
\text { laalxunup }\end{array}$ & $\begin{array}{l}\text { |khünùròb, |khunudab, } \\
\text { łkhàri"gàłònn nèb/-łènnèb }\end{array}$ \\
\hline liver & kx'âip [K] & åaís \\
\hline lizard sp. (10cm) & glabarip $[\mathrm{K}]$ & $?$ \\
\hline lizard sp. (striped, 30cm) & glâis [K] & |gàîs \\
\hline load $v$ & !nao & !näò \\
\hline $\operatorname{lock} v$. & *ł'ankx'am, *ł'an'am & łga̋nám \\
\hline locust & f'homs & łhömmi \\
\hline long for & $\|$ xoo & \|khórè \\
\hline \multirow[t]{2}{*}{ long-eared fox } & !xamap & !khàmäb (= silver jackal) \\
\hline & \|'aake, \|'aaki [K] & \|áàb (= bat-eared fox) \\
\hline look & !aba & 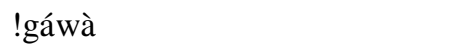 \\
\hline look back & !abakx'oa & kòö-óà (= look back to past) \\
\hline look behind/back & !aba!xuni & kòőǹ(kháò)!gạ́à \\
\hline loose the way & \|'habu & \|hàwü, kàà \\
\hline lost & kaa & káà \\
\hline louse & kx'urip & úrìb \\
\hline love $v$. & \|'âa; *łnam (??) & \|àặ Inäm \\
\hline love $n$. & \|'âap & \|àäb, Inämmi \\
\hline lung & $\begin{array}{l}\text { sookoi(-ku), } \\
\text { sookui(-ku) [K] }\end{array}$ & sòőb, (sòëb) \\
\hline lynx & |x'aba|'hôap, l'abal'hôap & läwálhòäb [N]; !häàb \\
\hline \multicolumn{3}{|l|}{$\mathbf{M}$} \\
\hline maggot & *|'uni (-ka) & fùnìb (= worm) \\
\hline magistrate & gaop & |görà!gạ̋á-àöb \\
\hline maiden & oaxais & őáxáès, łkhàmkhòès \\
\hline $\operatorname{man}$ & khoep & khöèb, áòb \\
\hline man-strong & $\neq x a r a m a p$ & $\begin{array}{l}\text { łkháràlnàä hàaäb (= matured man) } \\
\text { !gảrí-àöb }\end{array}$ \\
\hline man- young & kx'arop $[\mathrm{X}]$ & axarob = áàxäròb, áàxä-àöb \\
\hline mane & |'haup & |gàrëb \\
\hline & & |häúb (= goatee, beard) \\
\hline manner & f'uup & |gàüb; f'űúp (= character) \\
\hline many & $\begin{array}{l}\text { l'oosa }[\mathrm{X}] \text {; łui }[\mathrm{K}] \\
\text { harasa }\end{array}$ & fgùi", łà̀ùsä \\
\hline
\end{tabular}




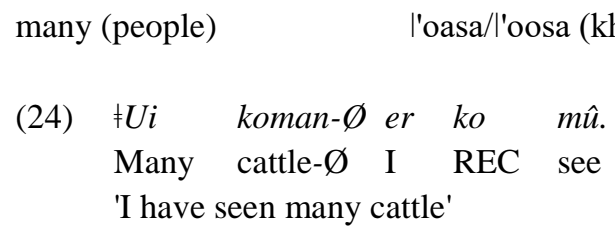

meat

Hee gllanni ke (n)‡'hanu tama. this meat IND right(?) NEG

haas głaep [X]

\|'aaxae [X]

xael'âi, g!amme $[\mathrm{K}]$

g\|anni, kx'oop

( $¥$ hanu $=$ right; correct, proper)

'this meat is not good'

$\begin{array}{ll}\text { meerkat, suricate } & \text { xarap, l'aep, ł'aup } \\ \text { meet } & * \text { !'hoo!'oa, !xoo!'oa } \\ \text { melt } v . i & \text { tshuni, thuni } \\ \text { mend (clothes) } & \neq \text { x'abo, ł'abo } \\ \text { message } & \text { *łôap } \\ \text { milk } n . & \text { daip, biip } \\ \text { milk } v . & \text { |x'ao, l'ao } \\ \text { milk (sour) } & \text { |xurudaip } \\ \text { milk - curdled ... } & \text { *âudaip } \\ \text { milk bag } & \text { !abap, !aballhoop/s } \\ \text { mind, move out of way } & \text { łoo, łoobasen }\end{array}$

Daop- $\varnothing \quad x и \quad r \quad$ na $\neq$ ‡oo. way- $\varnothing$ from I PR step.aside 'I am moving out of the way'

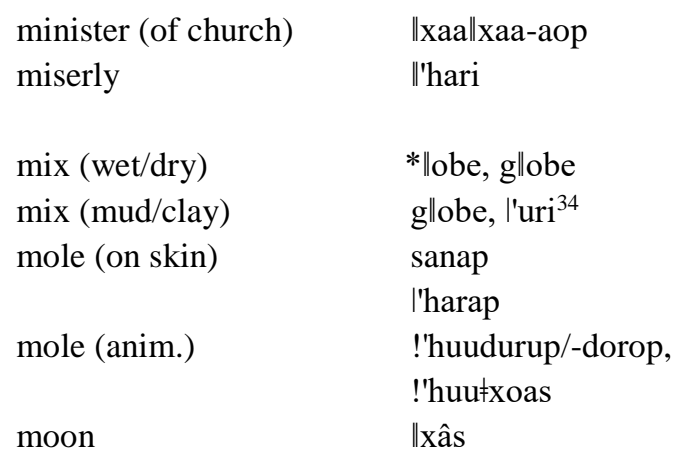

łgui $($ khoen $) \quad($ loasa $=$ full $)$

$\ddagger$ Gui goman-a ta ge go mû. many cattle-OBL I IND RECsee

häás

4

łgàéb

\|ằxáègù

!gämmë

|gäńni
Nē \|ganni ge !gâi tama hâ. this meat IND good NEG PERF

$\begin{array}{lr}\text { xáràb (gen.) } & 4 \\ \text { |hàö, !őágù; !khòö!őá (= receive) } & 2 \\ \text { tsünì } & 4 \\ \text { !näwá (= patch) (fáwò = daub) } & 0 \\ \text { łhöàs/b, häìsì-áms } & 2 \\ \text { däìb } & 4 \\ \text { làő } & 4 \\ \text { |khùrüdàïb } & 4 \\ \text { àüdàìb } & 2 \\ \text { däì!gàwàs } & 3 \\ \text { łgóò } & 4\end{array}$

Daob-a xu ta (ge) ra $¥ g o o$. way-OBL from I IND PR step.aside $\begin{array}{ll}\text { \|khàà } \| \text { khàä-àòb } & 4 \\ \text { |gíixä; "harisa } & 0\end{array}$

(= arch. derog. greedy)

łgöwé (= esp. fat); häwá; lòre” 2

häwá; łgöwé (= mix esp. soft fat) 0

|gịís; sanas/b (= large mark) 4

|härás/b (= wart) 4

hawa(tsuru)b (?) 0

\|khạàb 4

\footnotetext{
${ }^{34}$ Supplied by Gerd Maerman.
} 


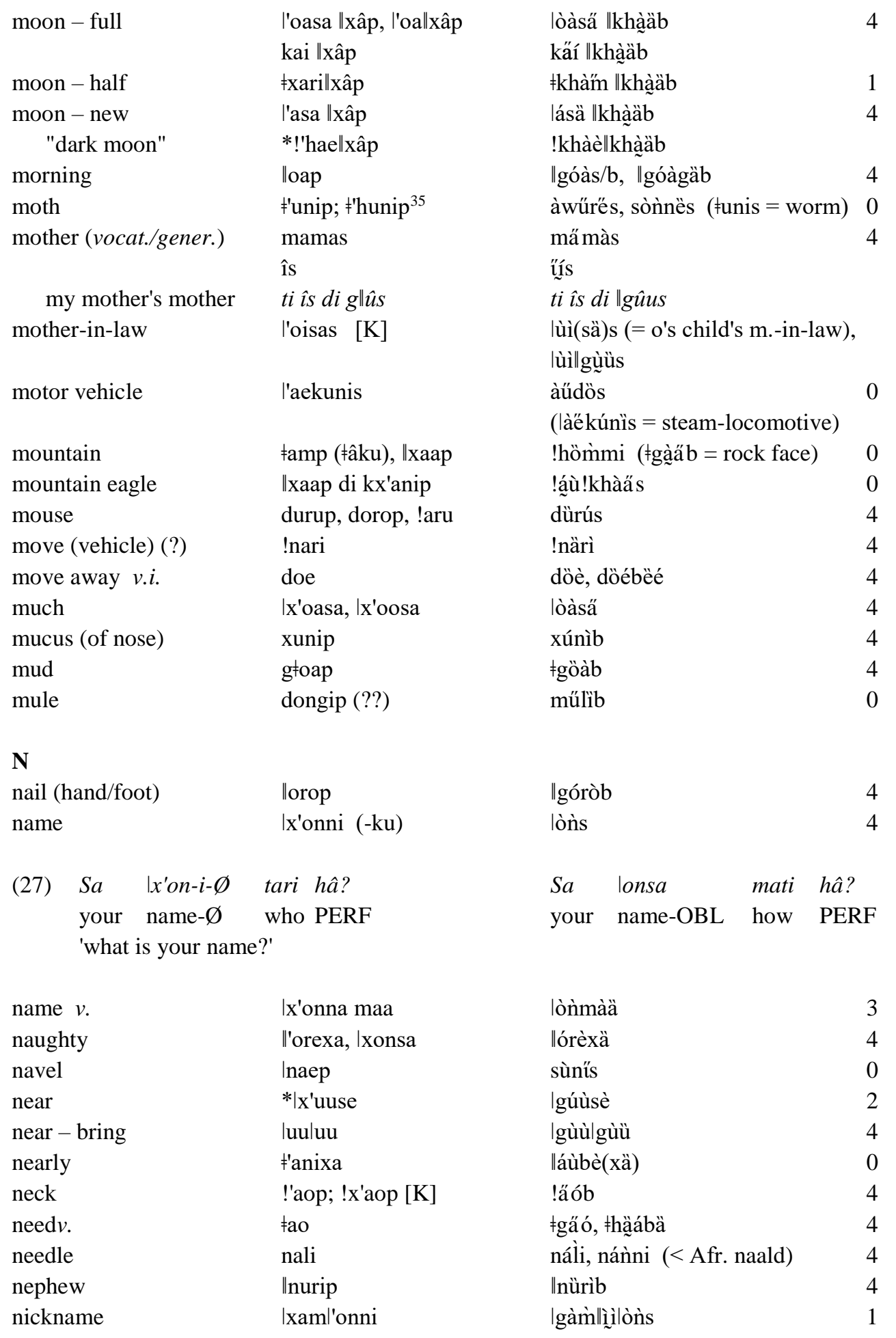

\footnotetext{
${ }^{35}$ Supplied by Gerd Maerman.
} 


\begin{tabular}{|c|c|c|}
\hline night & $\begin{array}{l}\text { tshuxuba, thuxuba, } \\
* \text { tjuxup }\end{array}$ & tsuxub [tsùüxúùp] \\
\hline nightjar & $\begin{array}{l}\text { !xaep, *!'haep } \\
\text { faakx'ailloes ("which } \\
\text { lies on plane") }\end{array}$ & $\begin{array}{l}\text { !khàèb (= darkness) } \\
\text { a̋wúhîíòb, łgáàllgőéb }\end{array}$ \\
\hline nine & !nanil'â (??) & khöèsè (!nänílà = sixteen) \\
\hline nip, pinch & $\|$ xai & \|khìï, \|khàì, \|khìrï \\
\hline nipple & sammi l'ammi $[\mathrm{K}]$ & sảmáḿs \\
\hline noise & łxubip, l'haap & łkhüwíb \\
\hline nose & głuip $[\mathrm{X}]$, głuis $[\mathrm{K}]$ & łgüís \\
\hline not negative marker & tama & tàmà \\
\hline \multicolumn{3}{|l|}{$\mathbf{O}$} \\
\hline old & kaira, kaida & käírà \\
\hline $\begin{array}{l}\text { omasum, leaf-stomach } \\
\text { |x'aras }\end{array}$ & $\begin{array}{l}\text { !nubup - bâ!'âs, } \\
\text { (láràb = abomasum) }\end{array}$ & łgùillhämísës \\
\hline omasum - contents of & f'haup & fhäùb (= fresh dung) \\
\hline & f'ama, *ai & áì \\
\hline on (be on something) & ł'amka & łámàì \\
\hline one & lui & |güí \\
\hline open $v . t$ & $* \|$ xoba-am & \|khòwä-ám̀ \\
\hline Orange River & ¥Nuug!arib & !Gärìb \\
\hline ostrich & l'amip & làmìs/b \\
\hline otter & \|amnłarup & !hömmíi, \|omitsillâab \\
\hline out & łx'oasi, キ'oasi, f'ui & fòä \\
\hline owl & !'huuros; !'hû!'hûs [K] & $\begin{array}{l}\text { !hựúròs (= pearlspotted owl) } \\
\text { |honnos }\end{array}$ \\
\hline \multicolumn{3}{|l|}{$\mathbf{P}$} \\
\hline pack $v$. & l'hami & $\begin{array}{l}\text { Ihämí } \\
\text { (= gather belongings for journe }\end{array}$ \\
\hline pack-ox & !arip & ! gärúb \\
\hline pain $v$. & tshû $[\mathrm{X}]$; thû $[\mathrm{K}]$ & tsụ̈ù \\
\hline palate & *!'harukx'ammi & łkhàrùb, nàm!hànäb \\
\hline pan, vley & !xubip & !khùwìs \\
\hline paper & $\ddagger$ xanip & łkhàníb \\
\hline pass $v$ & !xaru & !khàrü \\
\hline passive suffix & -he & -hë \\
\hline past tense & $* * \mathrm{ko}$ & gö, (gë) \\
\hline peace & †xâip & $\neq$ khiînb \\
\hline peck up & "'haakhâisi & \|hòwëkhäí \\
\hline peel $n$. & sorop & sòrőb \\
\hline peep & f'ui & łùĭ \\
\hline penis & xâp & xààà, !gäráb, lőáb \\
\hline perpendicular & \|naallôana, g!amallôa & łgöòłhànù \\
\hline person (a friendly ...) & kx'âikx'aop & khöèxä!nàà khòëb \\
\hline
\end{tabular}




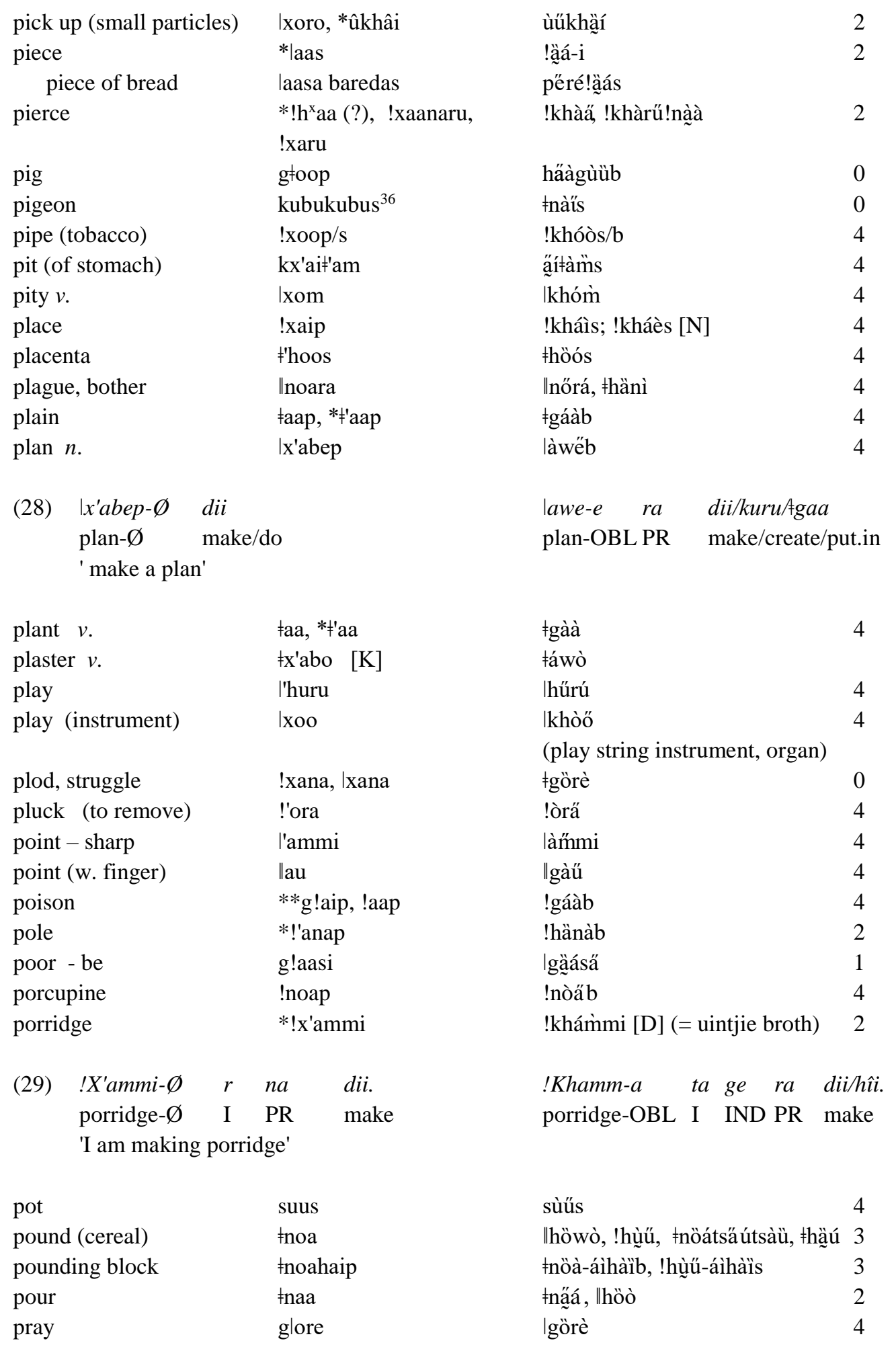

\footnotetext{
${ }^{36}$ Supplied by G. Maerman.
} 
predator

prepare/brey (skin)

g|arallûp ${ }^{37}$

Inoro

(30)

Ben_ ke na kaop- Ø Inoro.

Ben IND PR skin- $\varnothing$ brey

'Ben is breying a skin'

present tense

na

(31)

$\begin{array}{llllll}\text { Mû } & r & \text { na } & \text { sîsen } & \text { na } & \text { khoep- } \varnothing . \\ \text { see } & \text { I } & \text { PR } & \text { work } & \text { PR } & \text { man- } \varnothing\end{array}$

'I am seeing the working man'

$\begin{array}{ll}\text { press } & * * g \| \text { âi } \\ \text { prick } & * ! \text { 'haa } \\ \text { proud } & \text { !uri } \\ \text { puff-adder } & \text { !ais } \\ \text { pull } & * * \text { głae, fae } \\ \text { pupil (of eye) } & \text { łnuumûs } \\ \text { pursue (walking) } & \text { kx'ao!â! û } \\ \quad \text { (running) } & \text { kx'ao!â!xoe } \\ \text { push away (w.foot) } & \text { ł'haabee } \\ \text { put away } & \text { sâubee, \|xan } \\ \text { put down } & \text { łnûi } \\ \text { put together } & \text { łnui(n)|'hao }\end{array}$

Q

quarrelsome

!xamxa

!nubus

quail

quickly

quiet - be

!'haese

!noo

$\mathbf{R}$

raft

rain

bâs

tuup

rainbow

|'hôas / tuus *!'anap

Grewia sp. ‡x'âugłararap, ł'âun

ram

rape

łxaraguup

xae

rat

raw, cf. rude !nurullaus ${ }^{38}$

kx'oara xämánī-i

Inőró

0

4

Benni ge khoob-a ra Inoro.

Ben IND skin-OBL PR brey

$\mathrm{ra} / \mathrm{ta}$

Mû ta (ge) ra sîsen ra khoeb-a

see I IND PR work PR man-OBL

\|gàì

2

!khàä

2

!gùri" (= insubordinate) 4

!gàís [N]; !gàês 4

łgáè $\quad 4$

łnüùgòràs, àuútsíłgàrès $\quad 0$

!gờà!gòn 0

däá!gẵ $\quad 0$

†häábëé 4

\|gùïbëé 0

mäí, łnüí 4

łnùil'|hào 4

!kháṁxä, \|nùnìxä, gòwàxä 4

!nàwàrís, !häús 0

!häésè 4

!nòő 4

?

Inànüs, tüús [D, Topn., Bond.]; 4

làwíb [N]

tüú!hànäb, làwï !hànäb 2

łàuún, fa्aún 4

bäíb, łkháràgùüb 4

|gäi!khóò (xäé = have 0

intercourse)

dürúb 0

òrà 2

${ }^{37}$ Supplied by G. Maerman.

${ }^{38}$ Supplied by G. Maerman. 


\begin{tabular}{ll} 
ready cooked & \|'ansasa \\
receive & !xoo!'oa, *!'hoo!'oa \\
recover from illness & khoesi \\
red & |x'aba \\
reed & ł'aap \\
reed flute & ł'aap \\
refuse & łxaa \\
regret & *łaothuu ("heartsore"), \\
& \multicolumn{1}{c}{ !'haołao } \\
relative & \|'omap \\
remember & ł'âi \\
remind & ł'âił'âi \\
repair & ł'hanu (??) \\
request & łao \\
resembling one another & luiti-ii \\
reside & hâ
\end{tabular}

\begin{tabular}{|c|c|}
\hline \|a̋ńs"á & 3 \\
\hline !khòő!őá & \\
\hline łùrü & \\
\hline làwä & \\
\hline fáàb & \\
\hline fáàb & \\
\hline łkháà & \\
\hline !häúsèn; tsüüuäłgáò (= feel sad) & \\
\hline khöèxäbëb, lùi(khòë)-i & \\
\hline fạ̀îhőó, !khòőmạ̄í (łạ̀î = think) & \\
\hline fậ́1́ạiì!nå̀à, !nàwe̋!nàwë!nà̀à & \\
\hline łhänúłhànü (†hànü $=a$.correct $)$ & \\
\hline łgàn’ ; łgäólkháà (= demand) & \\
\hline |güítí-ìi,, òa̋sèn & \\
\hline hạ̄á, làǹ & \\
\hline
\end{tabular}

\section{Hâ $\quad r$ ge na. live/dwell I IND PR 'I am residing '}

residence

rest

return $(v . i)$

rib

rich - bec.

ride (animal/cycle)) (vehicle)

Riet River

reticulum

ridicule

riem

rifle

ring (for finger)

ring (metal)

ringed cobra (?)

rise (of: sun)

river

rock bank hâ!xaip

l'oml'omsen

!'hoba, !'hobakx'oa

kx'oahaa, daakx'oa,

daba

Ix'arap [K]

!xuu

!abi

!nari

I'Oma!garip

\|anisa

!'hoo

!'hâup

!'abus, *\|'abus

|xunu!an-

!an $(-\mathrm{ku})$

łnuulx'aop (?? = "black snake")

f'oa, f'oaxa

g!arip

$\neq$ narab
$\|$ An ta ge hâ.

reside I IND PERF

hàaả!khàìb, \|àǹ!khàìb

4

sàaä, !hàuu

(lomlomsen $=$ give o.self a breather)

!höwà, óà; lärú

òàhäà (= come back)

làräb

!khùù

!gáwì

!närì

- (= łáà!àäb)

!nűwúpés

!höó

!häùb

!äwús

|khűnúłnưìidàs

răís, rèńgs

(< Afr./Ge. ring/Ring)

\|hüíb, !gőrébëb

\|häì, föáxä

!áàb, dömmmi

(!gärìp = river bank)

łna̋ wáb; łgèrẻb [D] (= bedrock) 0 


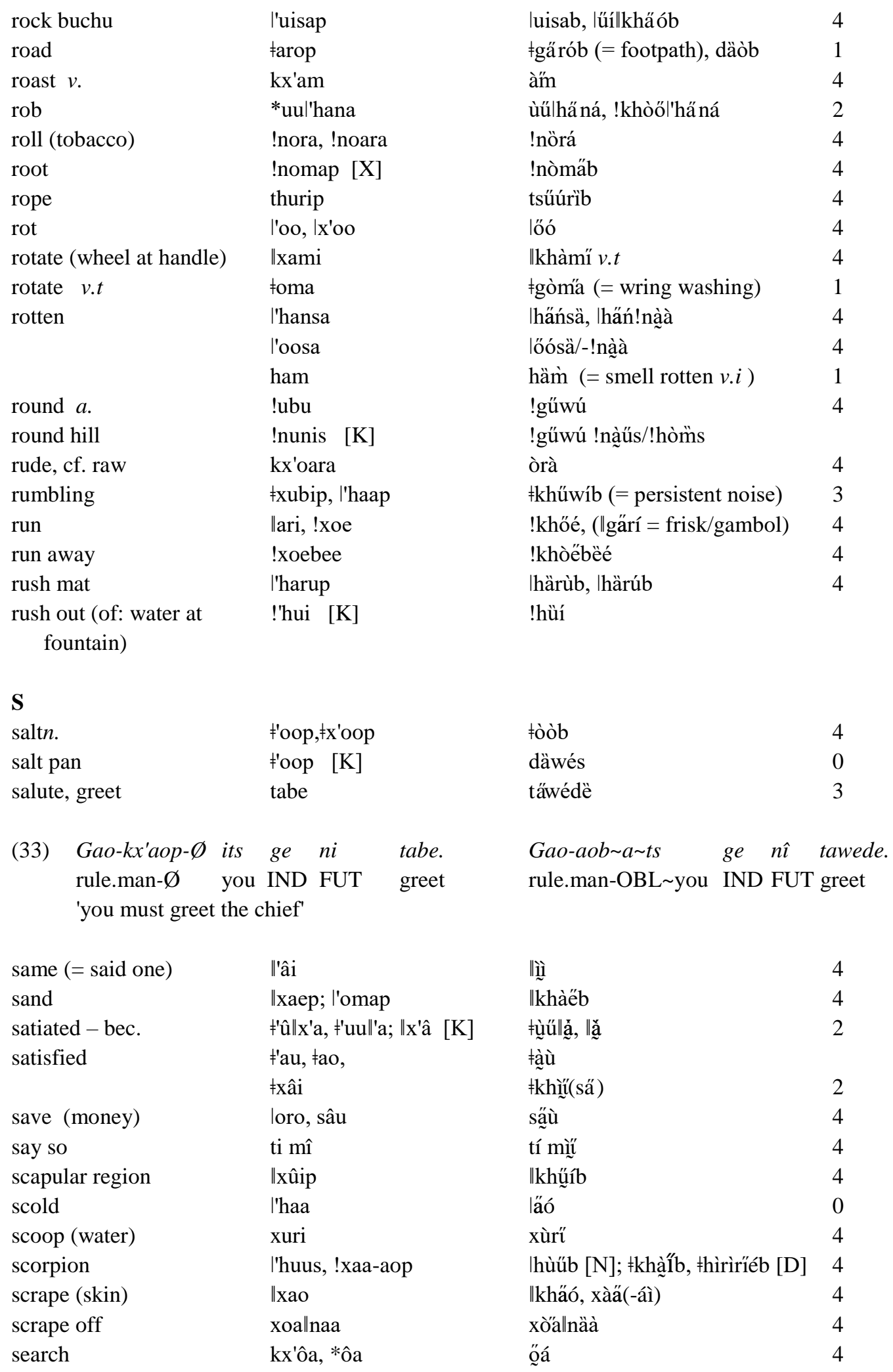




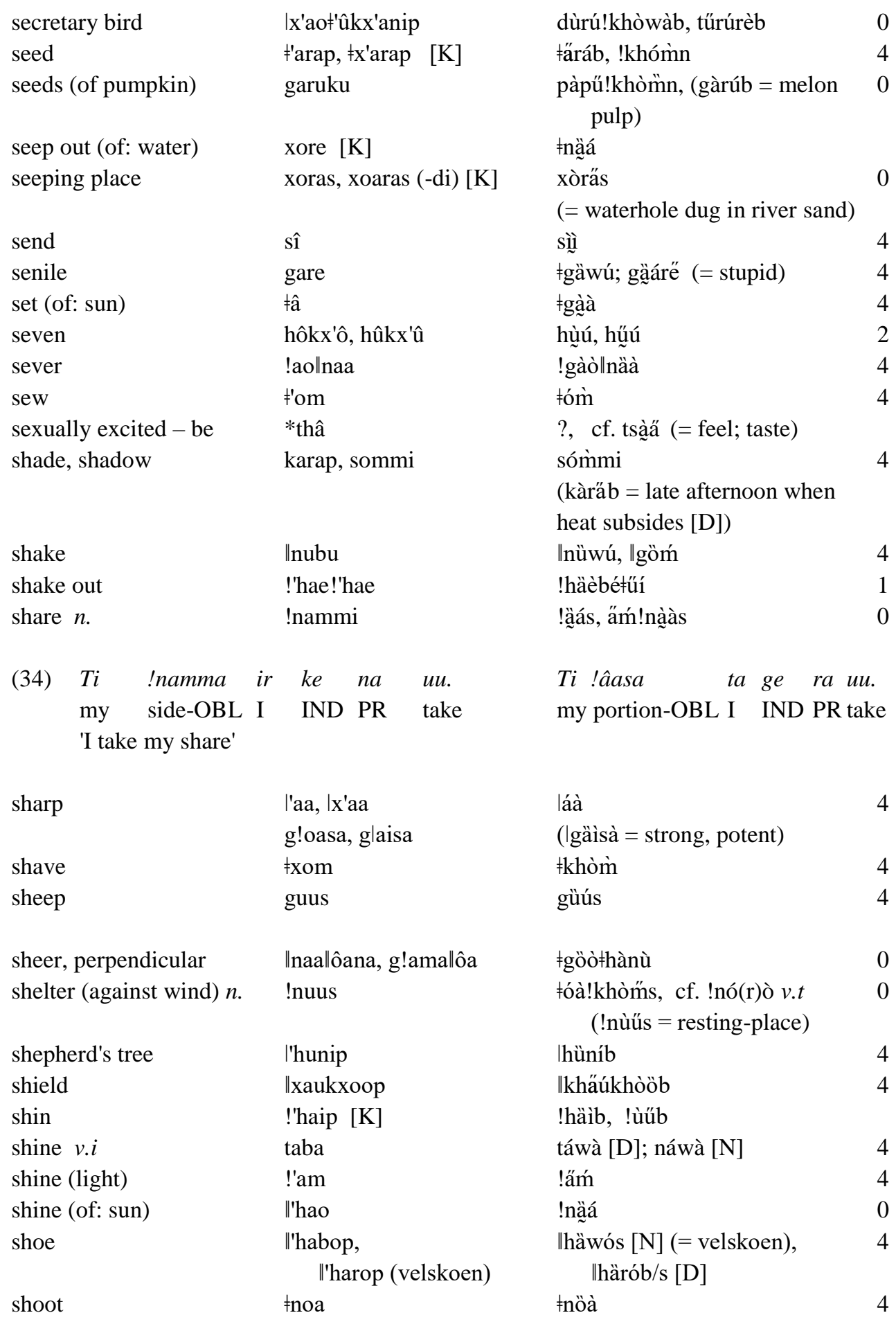

(35) Komas ke !'abu_lxa go łnoa-he. Gomas ge !abus |khago łnoa-he. cow IND rifle with REC shoot-PASS cow IND rifle with REC shoot-PASS 'the cow was shot with a rifle' 


$\begin{array}{ll}\text { shopkeeper } & \| \text { 'amaxuukhoep } \\ \text { short } & \text { !nubu, !nobu } \\ \text { shoulder } & \text { g\|arap } \\ & * \text { !hoop (Meinhof) } \\ \text { shoulder blade } & \text { g\|arap } \\ \text { shout } & \text { !'au, !x'au } \\ \text { show } & \| \text { au } \\ \text { shut (door) } & \text { *łanam } \\ \text { side } & \text { !nammi }\end{array}$

(36) Sa !nammi kx'ai na $r$ si-ma your side on PR I arrive.stand gaos !na. government in

'I testify on your behalf before the law'

side (of body)

left side

right side

sigh $v$.

sigh $n$.

silent - keep

silence

$\sin$

sinew

sister-in-law

sit

sit down

six

sjambok

skew

skin $v$.

skin $n$.

skunk

slanting

slaughter

sleep

sleeping-mat

sleepy

slender-tailed meerkat !'oms

lui |xaap arep,

!'arelxaap

*amlxaap

l'hail'om

l'ûmp

n!oo

n!oop

I'hubip

\|'abap

l'oisas [K]

‡nôa, łnoa

‡nû

!nani

!nabap

gama

f'aałàả

*kxhoop

!x'aa!x'aap [K]

furu

ł'aa, !'aaxadom, g!oe!ani $[\mathrm{K}]^{40}$

\|'om, \|'ôm

łaop (??)

f'umi

xarap \|àmäxùü-àöb

3

!nüwú

\|gäráb (= scapula)

!höós

3

|gäráb

!àu

"gàu

łgäńám

!nämmi

Sa |khaabai ta ge ra xatui. ${ }^{39}$ your side on I IND PR testify !nämmi

\|àre̋lkhäáb

àm|khäáb

|häímåííǹ̀̀̀

|häímåăíǹ̀̀ms

!nòö

!nòö(sï)b

\|órèb

\|áwàb

lùi(sä)s

łnòà $(<\neq$ Łù̀u hà̀à)

łnữú

!nàní

!näwàb

gàmá (= crooked)

\|näàlkháà

khòőb

!ùürőb, |gàmöröb

\|ảrésè

fàă (!gáòxädòm = slit throat)

\|óm

łgòäb

fòmhî̃, \|òmhî̃

xáràb

${ }^{39}$ xatui < Afrikaans getuig (testify)

40 Supplied by "old woman at Ritchie". 


\begin{tabular}{|c|c|c|}
\hline sole (of foot) & f'aip (di) kharup & fáì!näáb \\
\hline $\operatorname{slip} v$ & ‡xanu & łkhànù \\
\hline slippery & $\neq$ fxarisa & łkhìrìsä \\
\hline slowly & f'ause & fàüsè \\
\hline slow - be (i.e. talk less) & !ae!ae $[\mathrm{K}]$ & fàüsè (ra) !hóà \\
\hline small & 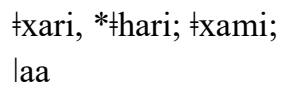 & $\begin{array}{l}\text { fkhàrí, lùì; } \\
\text { |gaa (Rust 1969: 74) }\end{array}$ \\
\hline smear (floor); anoint & $\ddagger$ хau & łkháù \\
\hline smile & Inum & |nőḿ \\
\hline smoke v.t & $\neq \mathrm{ae}$ & łgáè \\
\hline smoke $v . i$ & |x'an & láǹ \\
\hline smoke $n$. & khabup & láǹni \\
\hline snake & |x'aop, łnaup & làőb \\
\hline snaring place & *!'huis & !khuis (?); !nùîs (= snare) \\
\hline sneeze & |x'am [X/K], |x'â & tsīi, sīl (lám = snort (of: horse)) \\
\hline snore & !xaru & !khárù \\
\hline snuff & głûiłaep & süní-i \\
\hline soft & thamsa & tsàürä, tsàmıä \\
\hline soil & !'huup & !hüúb \\
\hline son-in-law & l'uikx'arop [X/K] & lùì|gớàb \\
\hline sorghum & bari!'horop & $?$ \\
\hline sour & |xuru & |khùrü \\
\hline sow & tshoro & tsöró \\
\hline spark $v$. & !'ai & !áè \\
\hline \multirow[t]{2}{*}{ speak } & !'hoa & !hőá \\
\hline & koba & gòwà (= argue) \\
\hline spider & Inûis & Inüís \\
\hline spider (big black) & $* \mid$ nuus & |hùüs \\
\hline spine & \|'âłxoop & \|åaáfkhòöb \\
\hline spit & $\neq x^{\prime} \operatorname{ara}[\mathrm{K}]$, f'ara & fäárä \\
\hline spit (through teeth) & |xabi & lìri" \\
\hline spleen & $\neq$ nubis & łnüwìs \\
\hline splinter $v$. & !xare & fkhàrè \\
\hline spoil & $\neq x^{\prime}$ oha & \|güí \\
\hline spoon & $\begin{array}{l}\text { Ikxammi, |xammi, } \\
\text { g\|oap }{ }^{41}\end{array}$ & \|göàb \\
\hline spotted & too & tòő; füúrä [N] \\
\hline springbok & \|ûp/s & \|gừüb; fhäáèb [D] \\
\hline springtrap & !xooluris & !nùîs \\
\hline spy on & !aba!aba & !khë!gă \\
\hline squint & !xâ & !kha्aá \\
\hline stab & !xaa; *!haa & !khàä \\
\hline stalk & |xuri & |khùr"' \\
\hline
\end{tabular}

${ }^{41}$ Supplied by Jan Kok; a Nama? 


\begin{tabular}{|c|c|c|}
\hline stallion & (łkhara)haap & łkháràháàb \\
\hline stamp (grain) & $\neq$ noa & łnöà, łhäú \\
\hline stamp (maize) & !'hû & !hừü \\
\hline star & \|amaroda-i & |gàmürős \\
\hline stare (at) & !aba & !gáwà \\
\hline steal & |x'aa, |x'âa, l'âa & lằ, !nàrí \\
\hline steenbuck & |x'aba!'hai-e & !àrïs \\
\hline sting $\quad v$. & !xaa & !khăa \\
\hline sting (of bee) $n$. & xam-ap & !nòmmmi \\
\hline stinging-fly & |'hamkx'ailarup & göm|gì̀näb \\
\hline stingy & g!uixa & |gîixä \\
\hline stink & I'han, ham & häm, |häńä!nàà \\
\hline stir & huni & hùnı̈ \\
\hline stomach & !naap; \|xommi & !näáb ("khőḿs = rumen) \\
\hline stomach - contents of & l'harap & |häràb \\
\hline stone & l'uip & lüíb/s \\
\hline $\begin{array}{l}\text { stone plover (kom- } \\
\text { mando voël) }\end{array}$ & *ł'hai-anip & \|khàì-ànïb (= crowned plover) \\
\hline stoop & !'ai, f'ai & !nòmm !nòm̈sèn \\
\hline & !'hôa & !höà ( $a$. crooked) \\
\hline stop (activity) & l'uu [K] & lù̀ü \\
\hline strange & Ixara, Inii & !häò （|khàrà = different) \\
\hline other & |xara, Inii & |khàrà, Inịi \\
\hline strangers & !'haokhoen & !häòkhòën \\
\hline strap (cow) & $\|$ 'hau & \|hàü \\
\hline strict & $\|$ xoo & ॥khőó \\
\hline strike (w. hammer) & łnau & łnäú \\
\hline strike (w. fist) & łnoa & łnöà \\
\hline string & $* *$ thurip & tsüúrïb \\
\hline strong & $\begin{array}{l}\text { glaisa, *laisa } \\
\text { glaiglai }\end{array}$ & |gäìsä \\
\hline struggle w. & !xana & !khànä ( $=v . i$ be busy/engaged) \\
\hline stupid & gâre & ga्ăáre, gạàà \\
\hline & *g!ookhoe, ${ }^{* g}$ ! ooke & !khựúkë [D], !khòmpòó \\
\hline stutter & koba \|'oa & àìnàm, àìlàm \\
\hline suck & lom & |gòm \\
\hline suckle & bii & däísì \\
\hline suffice & f'âu & fà্ù \\
\hline sugar & $\neq x o n-i$ & sűgùrì-i, süíkèri \\
\hline summer & $\|$ xoonap & \|khùünäb \\
\hline sun & sorep & sórèb/s \\
\hline supper & !'uif'ûp & !úìłừùs \\
\hline swallow & tom & tóm, härá \\
\hline swear & loe & |góè \\
\hline sweat & *aosen & áòsèǹ, áòsèn \\
\hline sweep & Inau & |nàwü \\
\hline
\end{tabular}




\begin{tabular}{|c|c|c|}
\hline sweet & $\neq$ xon & łkhòn \\
\hline sweetness & $\ddagger$ ×onnip & łkhòn̈sïb \\
\hline swell & xâi & xà̀ï \\
\hline swim & *tshâ; thâ $[\mathrm{K}]$ & tsăà \\
\hline swim under water & $\neq$ naru $[\mathrm{K}]$ & -, (düù) \\
\hline swing (in a circle) & foma & säwú \\
\hline sword & łnuup & gòàb; łnuub (?) \\
\hline \multicolumn{3}{|l|}{$\mathbf{T}$} \\
\hline \multirow[t]{2}{*}{ tobacco } & baaxap & tápàgäb, mäàgä-i \\
\hline & & (< Herero omakaya) \\
\hline table & f'ûkx'aixuup, f'û'aixuup & täáb \\
\hline tack, thread (?) $v$. & naru & närù, tsőánä \\
\hline tail & f'arep & łäréb \\
\hline take & $*$ uu & üú \\
\hline take away & *uubee & ùübëé \\
\hline take care of & !ôasi & kőó!gåaà, !göró, \|ga̋ń \\
\hline take shelter from & laa & Igáà \\
\hline tall & gaaxuu & $\begin{array}{l}\text { ga(i)xu [gààxùü] / [gàìxùü], } \\
\text { !näòsä }\end{array}$ \\
\hline tame - bec. & $\ddagger^{\prime} a u, \neq x^{\prime} a u^{42}$, gaa & fàü \\
\hline taste $v . t$ & *tshâ & tsà्ä \\
\hline teach & $\|$ xaa\|xaa & \|khààlkhàà \\
\hline tear (drop) $n$. & \|amarop & \|gàmmrőb \\
\hline tear $v$ & doa & döá $v . i$, döà v.t \\
\hline & |xau v.t & 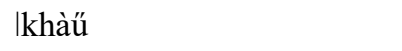 \\
\hline $\begin{array}{l}\text { tease (by pretending to } \\
\text { give) }\end{array}$ & $\|$ aellae & $\begin{array}{l}\text { mäá(gä)gäárä } \\
\qquad(\| \text { gáè\|gàè }=\text { mimic, ape })\end{array}$ \\
\hline teeth & \|ungku & \|güúgu \\
\hline tell & $\begin{array}{l}\text { !'hoaba, \|naa; } \\
\text { !hoaba }[\mathrm{K}]\end{array}$ & !hòäbä \\
\hline ten & dzisi & dî́sï \\
\hline $\begin{array}{l}\text { termite nest - aban- } \\
\text { doned }\end{array}$ & |'abip/!'abip l'ump & !gawes [D] \\
\hline testicle & $\neq x a r a p$ & łkhàràs \\
\hline glad (= grateful) & \|âixałao, !aixałao & !gạiäłgäó \\
\hline that demonstrative & $\|$ naa & \|nàä \\
\hline
\end{tabular}

(37) ॥Naa khoep ir na mû sîsen na. ॥Naa khoeb mûta ra-b ge ra sîsen that man I PR seework PR that man see I PR-he IND PR work 'that man whom I am seeing is working'

thatch $v$.

to

${ }^{42}$ Supplied by Katrina Brouers (Douglas). |gäwółàm!nà̀à, |güíłàm!nàà 3

-lîì, |nàälîì

3

4

4

2

(1)

4

4

4
4
4
4
4
4
0
4
4
4
0
4
2
4



(38) $\| N a a-\mid x^{\prime} a i \quad ! \hat{u} !$ there-to go 'go there!'

$\begin{array}{lll}\| N a a-\mid \hat{\imath} & ! g \hat{u} & r e ! \\ \text { there-to } & \text { go } & \text { HORT.P }\end{array}$

\|ìn

lạà-àöb, !nàrï-àöb

4

they

|'âin

|x'aamp, |x'âkx'aop

|'hôagaop

thieving

Ix'aamp

tîip ${ }^{43}$

timp $^{44}$

thigh-bone

tîiłxoop

I'ui

xuup

f'âi

!nana(sa)

\|â

!'âp

!'hâub

*\|'huup, \|xuup

!nona

!'arap, dommi

-!xaru

*!'haa!xaru

f'ûku

!nanip

kâitsîs [K]

**!urup

**! uru

!'oarabep

\|'aep

doros

I'hubu

!'oa, g\|a

to us/me |hòảkàőb (= crook)

lå̃s/b, |å̃sìs, !nàríb

tî̀ s/b

tîiłkhòòb, käíkkhòòb 4

|'ùì

xúùb

fàì

!na̋ná

"gà̀ä

!àäb (= boot-/shoe-lace)

!hà्ùb

\|khùüb

!nöná

dömmi

-!khàrü

!khàä!khàrű

!gäú

khäwús

käítsî||güúbës

!gürùb

!gürù

!òräpép

\|ảéb

dörós

|hùwü, tsàü

!òä, \|ga [\|̀ä]

tita !oa/ga, sida !oa/ga
2
(39) Kx'ommi $g \|$ a $\quad r \quad$ na $\quad$ û. house to I PR o

'I am going to the house'

toe

f'aip |xunup

zîp [K]

toe - big
Oms \|ga ta ge ra !gû. house to I IND PR go

${ }^{43}$ Supplied by Klaas.

${ }^{44}$ Supplied by Jan, Emma, Angelina.

łáilkhünús

tsiìib/s

tsiìib/s 


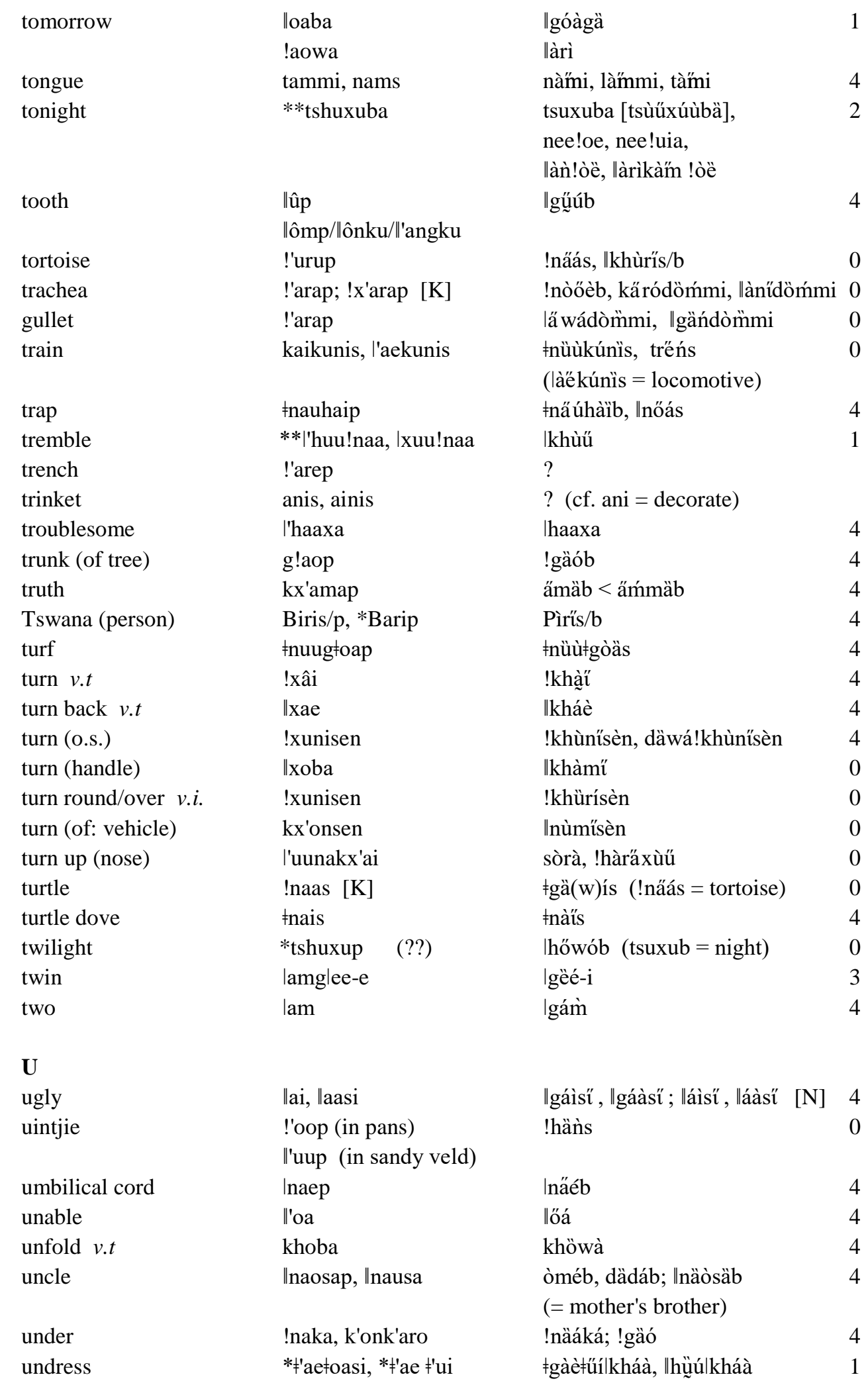




unhappy
unlock
unscrew
urinate
urine
uterus
V
vaalbos
Vaal River
vagina (?? vulva?)
varicoloured
vein
veld

Venus

visit

vlei

voice

vomit

vulture

\section{W}

wade

wag-'n-bietjie bot.

wagon

wagon wheel

wagtail

wait, hold on !xoara

\|xoba

\|xoba

Ixam [K]

Ixammi

\|'hoos łkhììò!nà̀à

0

\|khòwäám

fgòmällnạà, òrë

|khäm, àül|gàm

lùùb

\|häás
3

0

0

2

kaurtship
l'Haig!arip [K]

$?$

lőás, |gäùs 1

tòö, füúrä 2

‡khürúb 4

làù 4

!gáròb (!hüúbäíb = world)

\|gőálgàmìrős, !úil|gàmìrős 2

sàrì 4

!gőáb (= depression) $\quad 4$

dömmi 4

|khựì, árà 4

käígòràs $[\mathrm{N}]$; käí-ànîs $[\mathrm{D}] \quad 4$

xànü 4

łáròs 4

künís 4

künílnüús 0

\|nä̀̀ 4

(40) $\|$ Nam aibe!

wait in.the.meantime

'wait a bit'

॥Nam aibe!

wait in.the.meantime

$\begin{array}{ll}\text { wait (for) } & \text { !'âu } \\ \text { walk } & \text { !ûu } \\ \text { walk (round s.thing) } & \text { !ûfnami } \\ \text { walk past } & \text { !û-iilxaa } \\ \text { walk backwards } & \text { kx'oa } \\ \text { wall } & \text { !nuup/s } \\ \text { waltz } n . & \text { fomas } \\ \text { want } v . & \text { "'anu } \\ \text { want to (do) } & \text { \|aa } \\ \text { war } & \text { torop } \\ \text { warm }- \text { bec. } & \text { \|xôa }\end{array}$

!àu

4

!gựù 4

!gựùłnämì 4

!gừù-ü|kháà 4

kha̋ódürú, khäó-òä 3

łnüwìłgòäb 0

?

łgäó, łhäábä 4

łgäó 0

törób 4

\|khơà $\quad 4$ 


\begin{tabular}{|c|c|c|}
\hline wart & l'harap & |häráb \\
\hline wash (garment) & $\|$ 'aa & \|a̋á \\
\hline waterhole in rock & \|urup & $\|$ kharub \\
\hline we & sida & sida [siìda] (= we exclusive) \\
\hline weak - bec. & $\neq x a b u$ & fkhàwù \\
\hline wear (clothes) & !xansen & łgàèłgààsèn \\
\hline weather & |'hommi & fóàb mãààïb (|hömmi = sky) \\
\hline well & kx'aap & $\begin{array}{l}\text { łgằb Bibl., tsäúb } \\
\text { (äáb = deep hole) }\end{array}$ \\
\hline west & $* *$ soregłaas & sórès di łgàaàlkháàb, hüríłòàs \\
\hline wet & |x'â, l'â & 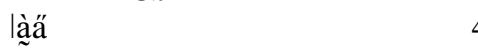 \\
\hline what? & tae? & tảré?, ta̋é? \\
\hline wheat & *|'hû(n)!horop & !höròb \\
\hline which & ham? & må̀ä?, hàm? \\
\hline when? & haml'ae? & màaá\| áè?, hàm\|àè? hàmmmő? \\
\hline where? & ham? & må̀äpä? \\
\hline whisper & tubu & túwù, sőwàbë \\
\hline whistle & łnam & łnäḿ \\
\hline white & !'uri, xati & !ùr"̈ \\
\hline who? & tari?, daa? & tàrï ?, tài" ? \\
\hline wild $a$. & !nari & !närí(sä) \\
\hline wild olive ${ }^{45}$ & !ommi, !omhaip & !goms \\
\hline win & daa & däà, däń \\
\hline wind $n$. & $\|$ 'aop & fóàb \\
\hline wind (strong) & ‡'oap & fóàb \\
\hline wing & $g \|$ abop & \|gäwòb \\
\hline \multirow[t]{2}{*}{ winnow } & **!'haa(l'ui) & !háà \\
\hline & f'aaburu & fóàpùrü \\
\hline wipe & l'om & lòm \\
\hline wire-worm & łnunip & ? (łùnìb = worm gen.) \\
\hline witgat Boscia albitrunca & |'hunip, *|honip & |hünís \\
\hline with & |xa & |kha [lkhàä] \\
\hline without & *ose & òsè \\
\hline woman & khoes & khöès \\
\hline womb & f'hoos & $\begin{array}{l}\text { łnùüü!gàùs, \|häás } \\
\quad \text { (†höós = afterbirth ofanimal) }\end{array}$ \\
\hline wood splinters & |x'oboku, |'aboku & |khàñni/-gu, lànàb \\
\hline \multirow[t]{2}{*}{ work, toil } & g!om & !ỏá \\
\hline & & (!göḿ $=a$. burdensome, onerous \\
\hline world & !'huup, !'huup(kx')aip & !hüúbäíb \\
\hline worm & f'unip & fùnìb \\
\hline wound $n$. & kx'uup & |hàwîs (üúb = pus) \\
\hline wring out (clothes) & f'omał'ui & fomałui \\
\hline wrinkle & |x'unip & \|gàî́ b \\
\hline
\end{tabular}

\footnotetext{
${ }^{45}$ Supplied by Jan Kok
} 
wrong

X

Xhosa

Y

yard

yarn

yawn

tired

year

yeast

yellow

yellow cow

yellowfish

yesterday

yesterday morning

yonder

young

youth (young man)

Z

zebra thuu, tshuu! $\mathrm{aa}^{46}$

*\|Hoosap

\|âup

l'abap

I'hubu

I'hubu

kurip

|xurup

I'hai, l'hao

I'hao gâap

I'hail'aup [K]

l'ari

|l'aatshe, |l'arikamtsheep

\|'arikam\|loa

\|naa, \|naaba

‡xam, ‡xami

|'ui-aop/-arop/

l'ui-kx'arop [K]

\|'arudaus tshüù, łkhàwà

4

\|Khóòsäb

2

\|gåùb

4

\|áwàb

4

gàà!găáá

0

(lhùwü $=$ bec. exhausted)

|hùwü, tsàü

kùríb

|khùrüb (= leaven)

!hünì (lhäí = pallid)

?

àrì

4

\|àrìkàmtsèë

\|àrìkàm\|lgòä(gà)

\|nàä, \|nàäpä

4

łkhàm

4

łkhàmkhòëb

0

!gőréb; !gőáréb [D]

0

${ }^{46}$ Obtained in Griekwastad. 


\section{Abbreviations}

\begin{tabular}{|c|c|}
\hline a. & adjective \\
\hline Afr. & Afrikaans \\
\hline AUX & completed/perfective aspect marker \\
\hline Bibl. & Biblical \\
\hline Bond. & Bondelzwarts (Nama) \\
\hline [D] & Damara dialects \\
\hline Engelbr. & Engelbrecht 1928 \\
\hline FUT & future/obligative marker \\
\hline Ge. & German \\
\hline gen. & generic/in general \\
\hline HORT.P & imperative/hortative particle \\
\hline IND & Indicative sentence type marker \\
\hline$[\mathrm{K}]$ & Korana/!Ora \\
\hline$[\mathrm{N}]$ & Nama dialects (of Namibian Khoekhoe) \\
\hline NEG & past/present negative marker \\
\hline PGN & person-gender-number marker \\
\hline PR & (present) progressive marker \\
\hline PRIV & privative \\
\hline PS & (present) stative marker \\
\hline REC & recent past marker \\
\hline REFL & reflexive \\
\hline Topn. & Topnaar (Nama) \\
\hline$v . i$ & intransitive verb \\
\hline v.t & transitive verb \\
\hline$[\mathrm{X}]$ & Xri \\
\hline$[\neq \mathrm{Aa}]$ & $\ddagger$ Aakhoe \\
\hline
\end{tabular}

\section{References}

Beach, Douglas Martin 1938. The Phonetics of the Hottentot Language. Cambridge: Heffer. du Plessis, Menán 2018. Kora: A Lost Khoisan Language of the Early Cape and the Gariep

Pretoria: Unisa Press (in collaboration with SA History Online).

Engelbrecht, Jan Anthonie 1928. Studies oor die Korannataal, in Annale v.d. Un. Stellenbosch $\operatorname{VIB}(2), 3-12$.

Ghomeshi, Jila, R. Jackendoff, N. Rosen and K. Russell. 2004. Contrastive focus reduplication in English (the salad-salad paper).Natural Language \& Linguistic Theory 22: 307-357.

Güldemann, Tom \& Anne-Maria Fehn (eds.), 2014. Beyond 'Khoisan': Historical relations in the

Kalahari Basin. Current Issues in Linguistic Theory 330. Amsterdam/Philadelphia:

Benjamins.

Haacke, Wilfrid H. G. 1999. The Tonology of Khoekhoe (Nama/Damara).Quellen zur Khoisan-

Forschung No. 16. Cologne: Rüdiger Köppe. (Ph.D thesis submitted 1992.) 2008. Tonogenesis in flagrante: Tonal Depression in Khoekhoe, Haillom, $\neq$ Aakhoe, 
!Gora and Naro, in Ermisch, S. (ed.) Proceedings of the 2nd International Symposium January 8-12, 2006, Riezlern/Kleinwalsertal. Quellen zur Khoisan-Forschung No. 22.153-183. Cologne: Rüdiger Köppe.

2011. Nama als Sprachbenennung in der Koloniallinguistik Deutsch-Südwestafrikas:

zwischen Endonym and Exonym. In Stolz, Th., Chr. Vossmann \& B. Dewein (eds) Kolonialzeitliche Sprachforschung: Die Beschreibung afrikanischer und ozeanischer Sprachen zur Zeit der deutschen Kolonialherrschaft. 139-160. Berlin: Akademie.

2013. The Syntax of !Gora, in Vossen, R. (ed.),The Khoesan Languages. 340-347.

London \& New York: Routledge.

2014. The Occurrence of Verb Serialisation in Khoe Languages: Convergence or

Divergence? in Güldemann, T. \& A.-M. Fehn (eds.),Beyond 'Khoisan': Historical relations in

the Kalahari Basin. Current Issues in Linguistic Theory 330. 125-151.

Amsterdam/Philadelphia: Benjamins.

2016. From 17th Century Cape Khoekhoe to 20th Century !Gora and Namibian

Khoekhoe, in Vossen, R. \& W. H. G. Haacke (eds.),Lone Tree - Scholarship in the Service of the Koon. Essays in memory of Anthony T. Traill. 209-235. Cologne: Rüdiger Köppe.

Haacke, Wilfrid \& Eliphas Eiseb. 2002. A KHOEKHOEGOWAB DICTIONARY with an EnglishKhoekhoegowab Index. Windhoek: Gamsberg-Macmillan.

Kirby, Percival R. 1939/40. The Diary of Dr Andrew Smith, Director of the 'Expedition for exploring Central Africa', 1834-6,Appendix II (2), 315-316. Cape Town: van Riebeeck Society.

Kroenlein, Johann G. 1989. Wortschatz der Khoi-khoin (Nama-Hottentotten). Berlin: Dt. Kolonialgesellschaft.

Louw, Jacobus A. 1986. Some Linguistic Influence of Khoi and San in the Prehistory of the Nguni, in Vossen, R. \& K. Keuthmann (eds.), Contemporary Studies on Khoisan. Quellen zur KhoisanForschung 5.2.141-168. Hamburg: Buske.

Meinhof, Carl 1930. Der Koranadialekt des Hottentottischen. Suppl. 12 to Zeitschrift für Eingeborenen-Sprachen. Berlin \& Hamburg: Dietrich Reimer.

Möhlig, Wilhelm J. G. 1983. Dialektometrie in Afrika, Methoden zur Messung synchroner sprachlicher Nähe, in Vossen, R. \& U. Claudi (eds.),Sprache, Geschichte und Kultur in Afrika.209-242. Hamburg: Buske.

Nienaber, G. S. 1989. Khoekhoense Stamname. 'n Voorlopige verkenning.RGN. Pretoria: Academia.

Nurse, George T. 1975. The origins of the northern Cape Griqua. Papers from the Institute for the Study of Man in Africa, 34. Johannesburg: Institute for the Study of Man in Africa.

Ponelis, Fritz 1975. !Ora Clicks: Problems and Speculations. In Traill, A. (ed.),Bushman and Hottentot Linguistic Studies 2. 51-60.Johannesburg: University of Witwatersrand.

Rust, Friedrich 1969. Nama Wörterbuch. Pietermaritzburg: UniversityNatal.

Snyman, Jan W. 1970. An introduction to the !X $\hat{u}$ (!Kung) language. Communications from the School of African Studies, \#34. Cape Town \& Rotterdam: A.A. Balkema for the University of Cape Town.

1975. Zul'hõasi fonologie en woordeboek. Communications from the School of African Studies, \#37. Cape Town \& Rotterdam: A.A. Balkema for the University of Cape Town.

Witzlack-Makarevich, Alena 2006. Aspects of Information Structure in Richtersveld Nama, unpublished M.A., Leipzig University. 
Wilfrid H. G. Haacke<whaacke@gmail.com>

4 Murex Street

Sunset Beach

Milnerton 7441

South Africa 